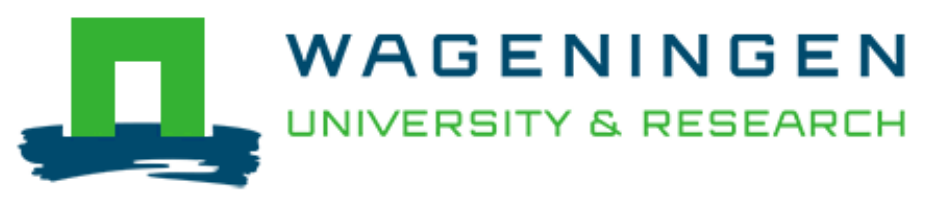

\title{
Role of the food matrix and digestion on calculation of the actual energy content of food
}

\author{
Capuano, E., Oliviero, T., Fogliano, V., \& Pellegrini, N.
}

This is a "Post-Print" accepted manuscript, which has been published in "Nutrition Reviews"

This version is distributed under a non-commercial no derivatives Creative Commons (c) $(\mathcal{Q} \Theta \Theta(\mathrm{CC}-\mathrm{BY}-\mathrm{NC}-\mathrm{ND})$ user license, which permits use, distribution, and reproduction in any medium, provided the original work is properly cited and not used for commercial purposes. Further, the restriction applies that if you remix, transform, or build upon the material, you may not distribute the modified material.

Please cite this publication as follows:

Capuano, E., Oliviero, T., Fogliano, V., \& Pellegrini, N. (2018). Role of the food matrix and digestion on calculation of the actual energy content of food. Nutrition Reviews, 76(4), 274-289. DOI: 10.1093/NUTRIT/NUX072

You can download the published version at:

https://doi.org/10.1093/NUTRIT/NUX072 


\title{
Role of the food matrix and digestion on calculation of the actual energy content of food
}

\author{
Edoardo Capuano, Teresa Oliviero, Vincenzo Fogliano, and Nicoletta Pellegrini
}

E. Capuano, T. Oliviero, V. Fogliano, and N. Pellegrini are with the Food Quality and Design Group, Wageningen University, Wageningen, the Netherlands. N. Pellegrini is with the Human Nutrition Unit, Department of Food and Drugs, University of Parma, Parma Italy.

Correspondence: N. Pellegrini, Human Nutrition Unit, Department of Food and Drugs, University of Parma, Parco Area delle Scienze 47/A, 43125 Parma, Italy. Email: nicoletta.pellegrini@unipr.it.

\begin{abstract}
The energy content of food is calculated on the basis of general factors for fat, protein, and carbohydrates. These general factors were derived by Atwater in the late 19th century, while additional factors for dietary fiber, polyols, and organic acids were introduced more recently. These factors are applied indiscriminately to all types of foods, yet the same nutrient may be digested to different extents to generate energy, depending on the characteristics of the food matrix, the processing methods applied to foods, and the meal composition. As a consequence, the actual energy content of food may differ from what is theoretically calculated with the Atwater factors. In this review, the relationship between macronutrient digestibility and food structure, macronutrient structure, and food composition is examined, and the implications for the amount of energy achievable through diet are highlighted. Estimates of the discrepancy between calculated energy content and actual energy content are provided for different diets. The findings may have implications for consumer purchasing decisions as well as for the design of dietary interventions.
\end{abstract}

Keywords: digestibility, energy content of food, food structure, nutrition fact, processing.

\section{INTRODUCTION}

The Nutrition Facts label on food packages is becoming an essential source of information for consumers. It provides information on the amounts of macronutrients, micronutrients, and energy in food products. ${ }^{1}$. Many consumers trust the Nutrition Facts label and will choose to purchase a certain product on the basis of the information contained in the label, depending on the calorie content shown. ${ }^{1}$

The calculation of the energy content of food refers to the amount of energy that the body is able to derive from the oxidation of food components. The energy content of food is therefore calculated by multiplying each energy-contributing food component by the corresponding heat of combustion. The highest value of energy achievable through food can be measured by using a bomb calorimeter, ie, by measuring the amount of energy released from the complete combustion of the food sample. However, in practice, only part of the energy-contributing component will be converted to energy because of incomplete digestion and, therefore, incomplete absorption in the gastrointestinal tract. In other words, the digestive system in humans is not as efficient an extractor of nutrients as is a bomb calorimeter. 
Several studies have reported that the compositional and structural features of foods can drastically change the bioavailability of nutrients and, therefore, the true nutritional value of the final product, thereby having a significant effect on energy intake. ${ }^{2}$ However, this evidence has not been fully applied to optimize the values of the Nutrition Facts. Therefore, consumers' choices can be influenced by uncorrected Nutrition Facts, particularly regarding certain types of food products.

The aim of this review is to claim the inaccuracy of the current Nutrition Facts and to provide scientific evidence substantiating the need to update them on the basis of new findings about the varying bioavailability of the macronutrients in different products. Table $1^{3,4}$ demonstrates this concept by comparing the energy values and the nutrient composition of dry roasted almonds and chocolate-coated cookies. The Nutrition Facts show that $100 \mathrm{~g}$ of cookies contains $13 \%$ fewer calories than $100 \mathrm{~g}$ of almonds. The higher caloric value of almonds is attributable to the higher lipid content of almonds. Such a difference in calories may prompt consumers to choose the cookies rather than the almonds. However, several published studies show that the bioaccessibility of lipid in almonds is drastically reduced by the almond cell walls that hinder the release of intracellular lipid, ${ }^{5-}$ 10 and the actual caloric content of 100 grams of almonds has been recently calculated in vivo as $460 \mathrm{kcal}$, ie, significantly lower than that reported in the Nutrition Facts. ${ }^{10}$ The bioaccessibility of lipid in baked products, such as cookies, has not yet been investigated. Nevertheless, this review will show that it can be assumed to be higher than that of lipid in nuts and seeds because bakery products are made with refined wheat flour and refined added fat, in which the typical cell structure of plant food is lost.

In this review, the nutrient availability and energy content of the main food categories are critically examined on the basis of the available knowledge about food structure and bioaccessibility. The Atwater factors, originally calculated to estimate the energy values of mixed diets, have important shortcomings in evaluating the energy content of foods because the gross energy content of dietary proteins, fats, and carbohydrates is not constant. Other chemical components of foods besides protein, fat, and carbohydrates contribute energy and may affect the energy content of foods. ${ }^{11}$ In addition, several other characteristics of foods can affect the energy content, including food structure. In this review, the current approach of calculating the energy content of food and, in turn, of diets, is reconsidered, focusing on how the intrinsic characteristics of the food matrix affect macronutrient digestibility and on how food processing, especially heating, affects such characteristics.

\section{How food energy is measured}

It is generally accepted that food energy values should reflect the amount of available energy in foods for the human organism, although opinions about the definition of available energy differ. In the last decade, an intense debate was sparked on this, and different approaches were proposed to evaluate the available energy and, in turn, the energy factors of foods. Mainly, 2 approaches were proposed: (1) calculation of the metabolizable energy, which corresponds to the heat obtained after the complete combustion of food in a bomb calorimeter minus that lost in feces, urine, body surface, and combustible gases, and (2) calculation of net metabolizable energy, which takes into account that not all of the metabolizable energy is available for the production of adenosine triphosphate. According to the latter approach, some energy is utilized during metabolic processes associated with digestion, absorption, and intermediary metabolism of food, the so-called obligatory thermogenesis, and some is lost as the heat of microbial fermentation. ${ }^{12}$ Thus, the net metabolizable energy represents the food energy available to the body after the heat produced during fermentation and obligatory thermogenesis has been deducted from the metabolizable energy.

All current systems used to calculate the energy content of foods are conceptually related to metabolizable energy. There are 3 systems currently in use, described below. 
The Atwater general system. The Atwater system is based on a substantial number of human experiments performed more than 100 years ago in which individual foods or mixed diets were analyzed to obtain digestibility values of protein, fat, and carbohydrate for different foods and diets. Atwater recognized that the digestibility of the same nutrient would be different in different food categories, yet he arrived at single, average factors for each of the energy-yielding substrates (protein, carbohydrate, and fat), regardless of the food in which the substrate is found, by calculating a theoretical average digestibility for each energy-yielding substrate in a mixed diet. The energy values are $17 \mathrm{~kJ} / \mathrm{g}(4 \mathrm{kcal} / \mathrm{g})$ for protein, $37 \mathrm{~kJ} / \mathrm{g}(9 \mathrm{kcal} / \mathrm{g})$ for fat, $17 \mathrm{~kJ} / \mathrm{g}(4 \mathrm{kcal} / \mathrm{g})$ for carbohydrate, and $29 \mathrm{~kJ} / \mathrm{g}$ (7 kcal/g) for alcohol. ${ }^{13}$ As originally described by Atwater, carbohydrate content of food is determined by difference (from the total weight once proteins, lipids, water and ash content has been determined), and thus includes fiber.

The Atwater extended system. This system was generated by adding some additional energy factors to those proposed by Atwater. For instance, a factor for available carbohydrate expressed as a monosaccharide (ie, $16 \mathrm{~kJ} / \mathrm{g}$ or $3.75 \mathrm{kcal} / \mathrm{g}$ ) was introduced, since it was recognized that carbohydrates have different weights, depending on whether they are complex or in the form of monosaccharides. Moreover, energy factors were included for dietary fiber (8 kJ/g or $2.0 \mathrm{kcal} / \mathrm{g}){ }^{12}$ organic acids (13 kJ/g or $3.0 \mathrm{kcal} / \mathrm{g}),{ }^{14}$ and polyols $(10 \mathrm{~kJ} / \mathrm{g}$ or $2.4 \mathrm{kcal} / \mathrm{g})$.

The Atwater specific factor system. This system is based on the re-examination of the Atwater system by Merrill and Watt ${ }^{15}$ in 1955 and revisited in 1973. The system focuses on the differences in digestibility values as well as the differences in heat of combustions of the same nutrient in different foods and uses category-specific conversion factors for proteins, fats, and total carbohydrates (no difference is made between available carbohydrates and dietary fiber), considering foods from different food categories and mixed diets. The proposed wide coefficients of digestibility ranged from $20 \%$ to $97 \%$ for protein and from $32 \%$ to $98 \%$ for carbohydrate, whereas those for lipid were much narrower and ranged from $90 \%$ to $95 \% .^{10}$

In the Atwater specific factor system, different energy factors of each nutrient from different foods are summarized in a set of tables. These factors ranged, for example, from $10.2 \mathrm{~kJ} / \mathrm{g}$ ( $2.44 \mathrm{kcal} / \mathrm{g}$ ) for some vegetable proteins to $18.2 \mathrm{~kJ} / \mathrm{g}(4.36 \mathrm{kcal} / \mathrm{g})$ for egg proteins, from $35 \mathrm{~kJ} / \mathrm{g}$ $(8.37 \mathrm{kcal} / \mathrm{g})$ for fats in vegetable foods (eg, grains, legumes, fruit, and nuts) to $37.7 \mathrm{~kJ} / \mathrm{g}(9.02$ $\mathrm{kcal} / \mathrm{g})$ for fat in eggs, and from $5.6 \mathrm{~kJ} / \mathrm{g}(1.33 \mathrm{kcal} / \mathrm{g})$ for total carbohydrates in cocoa chocolate to $17.4 \mathrm{~kJ} / \mathrm{g}$ (4.16 kcal/g) for total carbohydrates in polished rice. Such energy factors gave an accurate estimation of the available energy when applied to various diets containing foods of both animal and plant sources in both simple and more complex diets. ${ }^{15}$ The largest differences in the calorie calculation between Merrill and Watt's system ${ }^{15}$ and the Atwater general system were reported for those diets in which foods of plant origin predominated. Moreover, when Merrill and Watt ${ }^{15}$ grouped foods into a few large categories and calculated the average coefficients of digestibility and energy factors for protein, fat, and carbohydrate of each of these groups, they found that the energy factors were $4.00 \mathrm{kcal} / \mathrm{g}, 8.92 \mathrm{kcal} / \mathrm{g}$, and $3.97 \mathrm{kcal} / \mathrm{g}$ for protein, fat, and carbohydrate, respectively. These factors, if rounded to simple whole numbers, are the same as those of the Atwater general system, which is probably why the use of the Atwater specific factors proposed by Merrill and Watt ${ }^{15}$ has never been fully implemented.

The major differences between net metabolizable energy factors and metabolizable energy factors are evident when the energy content of 3 food components is estimated: (1) protein, for which the factor is $13 \mathrm{~kJ} / \mathrm{g}$ ( $3.2 \mathrm{kcal} / \mathrm{g}$ ) for net metabolizable energy, compared with $17 \mathrm{~kJ} / \mathrm{g}$ ( $4 \mathrm{kcal} / \mathrm{g}$ ) for metabolizable energy, a difference attributable to the fact that the thermogenesis due to 
ingested proteins exceeds that due to ingested carbohydrate over 24 hours or more; (2) dietary fiber, for which the factor is $6.2 \mathrm{~kJ} / \mathrm{g}(1.5 \mathrm{kcal} / \mathrm{g})$ for net metabolizable energy compared with $8 \mathrm{~kJ} / \mathrm{g}$ ( $2.0 \mathrm{kcal} / \mathrm{g}$ ) for metabolizable energy, a difference attributable to the energy lost through the heat of fermentation; and (3) alcohol, for which the value is $26 \mathrm{~kJ} / \mathrm{g}(6.3 \mathrm{kcal} / \mathrm{g})$ for net metabolizable energy compared with $29 \mathrm{~kJ} / \mathrm{g}(7 \mathrm{kcal} / \mathrm{g})$ for metabolizable energy, a difference attributable to the thermogenesis that occurs following the ingestion of alcohol.

As a consequence, the greatest discrepancy between energy values calculated using the metabolizable energy approach and those calculated using the net metabolizable energy conversion factors will be found when calculating values for diets and foods rich in proteins and fiber as well as for foods of low energy density. ${ }^{16}$

Although metabolizable energy factors are generally used for calculating the energy values of foods, different methods have been adopted by the regulatory agencies of different countries, resulting in nutritional facts that differ according to various nutritional advisory bodies and geographical areas.

Codex Alimentarius. The Codex Alimentarius Commission ${ }^{14}$ decided to use Atwater general factors for calculating the energy values of food, with additional factors designated for alcohol and organic acids.

European Union. The European Union regulation on the provision of food information to consumers (Regulation EU No. 1169/2011) ${ }^{4}$ is based on the Atwater extended system, but no distinction is made between monosaccharides and polysaccharides.

United States. The US regulation ${ }^{17}$ allows the use of several methods when determining the energy values of foods for nutrition labeling, including the Atwater general system, the Atwater specific system, and bomb calorimetry minus $1.25 \mathrm{kcal}$ per gram of protein to correct the incomplete digestibility.

Canada. According to the Canadian regulation ${ }^{18}$, the energy value of foods should be calculated by the Atwater specific factor system, using specific factors from the latest revisions of US Department of Agriculture's Agriculture Handbook No. 8: Composition of Foods. This regulation also states that the average factors (ie, Atwater general factors) may be used in place of the specific factors, provided that the energy values are in reasonable agreement with the most accurate values determined according to Merrill and Watt. ${ }^{15}$

\section{FACTORS AFFECTING THE DIGESTION OF MACRONUTRIENTS}

Despite what some minor compounds (polyols or organic acids, for instance) may contribute, the actual caloric content of foods depends mostly on how much of the ingested proteins, lipids, and carbohydrates are absorbed by the small intestinal epithelium. Macronutrients must be hydrolyzed into smaller products before they can be absorbed by the intestinal epithelium. This process can be very efficient, with more than $90 \%$ of the hydrolysis products from macronutrients being absorbed in the upper intestine. However, the amount of macronutrients that escape digestion may be very large for certain foods or diets. Three specific factors regulate the digestion of macronutrients after the consumption of food: (1) the natural structural barriers to the digestion of macronutrients, ie, the food matrix; (2) the structural organization of macronutrients; and (3) the 
dietary components that interfere with digestive processes. These factors are shown schematically in Figure 1.

The first and most important factor is represented by structural barriers, which prevent or delay the encounter between macromolecules and digestive enzymes (Figure 1, panel A). In plantbased foods, this structural barrier comprises the continuous network of cell walls. The cell wall provides mechanical resistance, support, and protection to the plant cell. Since cell walls are made of nondigestible polysaccharides (commonly known as dietary fiber), they remain largely unaffected during digestion. If cells remain intact at the moment of swallowing, intracellular macronutrients can come in contact with digestive enzymes only if the cell wall's pore size is large enough (Figure 1 , panel A1). This will hinder or delay their digestion. So, it is clear that the degree of integrity of the food matrix at the moment of swallowing strongly affects the digestibility of macronutrients in plant foods. In other words, the degree of integrity of plant cells largely determines the kinetics and the extent of macromolecular digestion and, hence, the caloric content of plant foods. In processed foods, additional microstructural barriers may be introduced, such as a continuous network of gluten proteins in bread and pasta, which encapsulates starch granules, or a continuous network of casein protein in cheese, which encapsulates fat globules (Figure 1, panel A2).

The second factor is represented by the structural organization of macronutrients (Figure 1, panel B). In plant foods, starch, proteins, and fats are deposited in granules or bodies of varying size and structure, often tightly packed within the cells. Sometimes these structures are also protected by additional layers (eg, oleosins proteins in oil bodies). The size and the shape of these bodies and, in turn, the surface exposed to digestive fluids influence the digestion kinetics and the extent to which the bodies are digested. Apart from bodies and granules, macronutrients in food may form a vast array of structures that are digested through different kinetics. Proteins, for instance, may be found in food as random coil polymers, aggregates, networks (bread and pasta), fibers (meat and fish), gels (yogurt and cheese), emulsions, etc.

The third factor is represented by other dietary components that are simultaneously present in the digestive system and interfere with the digestibility of macronutrients (Figure 1, panel C). They may reduce digestibility in a variety of ways, as follows: (1) by interacting with macronutrients, thus shielding them from digestive enzymes; (2) by insolubilizing macronutrients, enzymes, or products of enzyme hydrolysis; (3) by inhibiting the catalytic activity of digestive enzymes; or (4) by modifying the colloidal properties of the bolus/chyme in such a way as to slow the hydrolysis of macromolecules, for instance, by stabilizing lipid emulsions or by increasing the viscosity of the digesta. Examples of such dietary components include dietary fiber in all plants, glucosinolates in brassica vegetables, trypsin inhibitors and hemagglutinins in legumes, phytates in cereals and oilseeds, gossypol in cottonseed, and tannins in several plant sources. ${ }^{19}$

The following sections describe how the 3 above-described factors may decrease the digestibility of each of the major macronutrients, ie, lipids, starch, and proteins.

\section{Lipid digestion}

In the absence of food structural barriers, free fat/oils are almost completely hydrolyzed by gastrointestinal secretions. However, emulsion properties (droplet size distribution, flocculation/coalescence, type of surfactant, etc) affect the rate of lipolysis. ${ }^{20}$ In oilseeds, lipids are stored in oil bodies, which are covered by a thin layer of phospholipids and proteins. These proteins protect the oil bodies from coalescence during gastric digestion but are displaced by bile salts in the small intestine. In foods of plant origin, however, encapsulation within the intact cell wall can strongly reduce lipid digestibility. This has been repeatedly demonstrated in almonds. ${ }^{5-10}$ Mastication of almonds produces particles of variable size that contain intact cells. These particles pass relatively 
unaffected through the stomach and the small intestine, resulting in a remarkable amount of lipids that travel through the gastrointestinal tract encapsulated within intact cells that limit the extent of lipid digestion. It has been estimated that the actual caloric content of almonds is approximately $30 \%$ lower than that calculated on the basis of the Atwater general factors. ${ }^{10}$ Assuming that only the fraction of lipids escaping from fractured cells at the moment of swallowing can be hydrolyzed in the small intestine and that the fraction of fractured cells can be theoretically calculated from the particle size distribution and cell size, the amount of bioavailable lipids from plant-based food can be predicted. $^{21}$ Solid and brittle nuts and seeds, which, upon mastication, exhibit a fracture behavior similar to that of almonds, are likely to produce particles of macroscopic size with a relatively high fraction of intact cells, ie, of inaccessible lipids. Indeed, it has been recently demonstrated that the actual metabolizable energy of walnuts is $21 \%$ lower than that theoretically calculated using the Atwater factors. ${ }^{22}$ It is likely that the inaccessibility of lipids encapsulated in intact cells is also the mechanism behind the higher level of fecal fat measured in vivo after the consumption of intact peanuts compared with peanut butter or peanut flour. ${ }^{23}$ Interestingly, pistachio nuts behave quite differently from almonds and walnuts, and the difference between the actual metabolizable energy and that calculated with the Atwater factors is only $5 \%,{ }^{24}$ which reflects a different mechanical behavior during mastication and a different share of inaccessible lipids. It is therefore quite clear that a variable amount of lipids in nuts and seeds is not digested, and this amount depends on both the physical properties of the nut/seed tissue and the chemical composition of the cell wall.

Lipid globules can also be incorporated into large protein structures or networks that may limit their accessibility to lipase. Cheese is a good example of this: caseins in coagulum consist of a network of casein micelles, which encapsulate fat globules, whereas the void spaces in the casein matrix are filled with the liquid milk serum, ie, a solution of lactose, minerals, and vitamins and a suspension of whey proteins. The accessibility of lipid droplets to lipase depends on the extent to which the droplets are embedded within the protein matrix, ie, the structure of the casein network and the size of the fat globules, so that degradation and the kinetics of fatty acids release are driven mainly by the physical characteristics of the cheese. ${ }^{25}$ Early studies reported that the digestibility of fat in cheeses ranges from $88 \%$ to $94 \% .{ }^{26}$ A recent study in pigs shows that fecal fat excretion was $20 \mathrm{~g} / \mathrm{d}$ higher after administration of regular-fat cheese than after administration of reduced-fat cheese and butter. ${ }^{27}$ Despite a correlation with the total amount of calcium in the diet (see below in this section, on the effect of calcium), the cheese matrix in which the fat was located also played a role, ie, fat in cheese is less accessible to lipase than fat in butter. Isocaloric diets containing an equal amount of lipids (and the same distribution of short-, medium-, and long-chain fatty acids) provided in the form of cheese or meat were associated with different levels of fat excretion. Fat excrection was higher with the cheese diet $(5.8 \mathrm{~g} / \mathrm{d})$ than with the meat diet $(4.9 \mathrm{~g} / \mathrm{d})$. Fecal excretion from both the cheese and the meat diets was higher than that from the carbohydrate-rich, low-fat control diet $(3.9 \mathrm{~g} / \mathrm{d}){ }^{28}$

Dietary components can also affect the extent of lipid digestion. Calcium in the food or diet may affect lipid digestibility by precipitating free fatty acids as insoluble calcium soaps. A meta-analysis of human intervention studies demonstrated an increase in dietary fat excretion in the feces upon dietary supplementation with calcium, either from supplements or from dairy products. ${ }^{29}$ It showed that a weighted-average increase in dairy calcium by $1241 \mathrm{mg} / \mathrm{d}$ produced an increase in fecal fat excretion of $5.2 \mathrm{~g} / \mathrm{d}$. This is equivalent to $47 \mathrm{kcal} / \mathrm{d}$ or $1.9 \mathrm{~kg}$ of body fat or $2.2 \mathrm{~kg}$ of body weight over 1 year. A diet rich in condensed tannins has also been shown to increase the excretion of lipid fecal fat. ${ }^{30}$ This may be attributable to the inhibition of lipase or to the excretion of bile salts, resulting in destabilization of lipid emulsion and less fat absorption.

\section{Starch digestion}


Starch is the main source of carbohydrate in the diet. When encapsulated within intact cell walls, starch may be digested more slowly, mainly because its encapsulation within intact cells limits the access of $\alpha$-amylase to starch. Starch that escapes digestion because it is physically inaccessible to amylase is usually referred to as type I resistant starch. In addition, starch encapsulated within intact cells may be only partially gelatinized during hydrothermal processes, making it less digestible. ${ }^{31}$ Several studies reported that up to $15 \%$ of legume starch escapes digestion in the upper digestive tract because of physical inaccessibility or partial gelatinization, thus reaching the colon, where starch can be fermented by the colonic microbiota. The same may apply to cereals, but the amount escaping digestion in the upper tract will vary widely between different cereals, depending on the restriction to water and heat transfer imposed by the cell wall, which in turn affects starch gelatinization. ${ }^{31}$ Studies in ileostomy patients have shown that starch encapsulated within intact cells is digested more slowly than free starch in wheat endosperm and has a beneficial effect on the management and prevention of diabetes. ${ }^{31,32}$ Accordingly, $17 \%$ of the starch from barley was not absorbed in the upper intestine of ileostomy patients when barley was provided as flaked particles of $3 \mathrm{~mm}$ in diameter rather than as flour. ${ }^{32}$ Levels of starch escaping digestion were relatively higher for whole rice (average $3.1 \%$ ) than for ground rice $(0.7 \%) .{ }^{33}$ In this respect, if the content of available carbohydrates is measured by difference and the method for quantification of dietary fiber does not capture type I resistant starch, the caloric content of the food may be overestimated. This is because a part of the unavailable starch would be classified as available carbohydrate. Moreover, some of the analytical procedures for the determination of dietary fiber consist of a milling step followed by very intense enzymatic hydrolysis. For instance, methods AOAC 2009.01 and 2011.25 (AACC methods 32-45.01 and 32-50.01), that have been recently adopted by Codex Alimentarius as a Type I methods comprise a grinding step of the food sample to obtain particles less than $0.5 \mathrm{~mm}$ in diameter. Grinding materials this finely results in a partial loss of the encapsulation effect on starch. This would result in a partial underestimation of the content of type I resistant starch when plant-based foods eaten whole are analyzed. To circumvent this issue, it would be advisable to replace milling/homogenization of the starchy sample with a gentle mincing or, even better, with a chewing-simulation step. Some currently used in vitro methods actually use real chewing by human volunteers rather than mechanical simulation of the oral step (see Table 1 in Woolnough et $\mathrm{al}^{34}$ ).

Besides the cell wall, other structural barriers in food may limit the digestibility of starch. In bread, bakery products, and pasta, starch granules are embedded in a continuous protein network composed of glutenin and gliadin fractions. The presence of this surrounding network may affect starch digestibility. Jenkins et $\mathrm{al}^{35}$ reported that the amount of unabsorbed starch (measured as hydrogen in breath) after consumption of white bread was $14 \%$. Notably, when the gluten network was removed, this value dropped to $7 \%$ and increased only slightly to $9 \%$ if the gluten was added back to the flour before baking. This clearly proves that the hydrolysis of starch is slowed not by the presence of gluten per se but by the network structure around the starch granules. The reduction of starch absorption was confirmed in other studies. Wolever et $\mathrm{al}^{36}$ reported that $11 \%$ and $8 \%$ of starch from white bread and wholemeal bread, respectively, was lost in the feces after consumption of white bread and wholemeal bread, respectively. The effect of the natural gluten network on the degree of starch hydrolysis in wheat-flour-based products was recently confirmed in vitro. ${ }^{37}$ It is not clear whether this effect stems from a limited accessibility of $\alpha$-amylase to starch granules or from specific interactions between starch granules and gluten. Pores of the gluten network are large enough $(0.5-40 \mu \mathrm{m}$ in diameter) to allow $\alpha$-amylase $(10 \mathrm{~nm}$ in diameter) to diffuse freely to starch granules. ${ }^{38}$ Nonetheless, amylase diffusion within the gluten network can be slowed by both the tortuosity of the network and the interactions of enzymes with gluten proteins. In pasta, starch granules are surrounded by a protein network even stronger than that in bread. More recently, the role of the gluten network in the hydrolysis of starch in pasta has been investigated in vitro. ${ }^{39}$ Beside shielding starch from $\alpha$-amylase, the gluten network also limits the transfer of water within the pasta strands during cooking, thus limiting the complete gelatinization of starch, especially at the core of 
the strand. However, so far, it is unknown whether the gluten network in pasta augments the level of unabsorbed starch in vivo.

In plants, starch is naturally stored in the endosperm of grains and tubers as granules of different size, shape, and structural organization. Granule size, shape, porosity, and level of crystallinity as well as the ratio between amylose and amylopectin all affect starch digestibility. Starch is much more susceptible to amylases when is in an amorphous rather than a (semi-) crystalline state. This is why gelatinized starch is much more digestible than raw starch. Gelatinization is a physical phenomenon that comprises absorption of water and swelling with disruption of the semicrystalline structure of the starch granule and leaching of amylose into the cooking medium. Starch granules are also associated with a varying amount of proteins, lipids, and other compounds (mainly phenolic compounds). These compounds may, in certain conditions, limit the accessibility of the granule to digestive enzymes or limit the extent of gelatinization upon hydrothermal treatments, thus reducing starch digestibility. Retrogradation of starch also results in the formation of starch fractions resistant to digestion in the upper intestine, known as type III resistant starch. Retrograded starch is captured by the analytical methods currently used for the determination of dietary fiber. However, retrograded starch formed during the storage of thermally treated starchy foods is not considered in energy calculations because the analyses are usually performed on the food as produced and not as consumed. Actually, cooked pasta, potato, and rice are less caloric if consumed the day after cooking, the severity of retrogradation being dependent on the storage conditions, mainly temperature. An increase in resistant starch is reported upon cooling of rice and potato after boiling. ${ }^{33,40}$ In ileostomy patients who consumed freshly cooked potatoes, only $3 \%$ of the starch was not hydrolyzed, whereas after consumption of cooled potatoes, $12 \%$ of the starch was recovered in the ileostomy effluent. ${ }^{41}$ It is also likely that the amount of retrograded starch would be very high in ready-to-eat foods subjected to prolonged storage, such as those produced for armed forces, in which up to $30 \%$ resistant starch has been measured. ${ }^{42}$

Pancreatic amylase can be inhibited by a number of dietary factors with varying degrees of efficacy. Protein inhibitors of $\alpha$-amylase occur widely in plants and have been long known. ${ }^{43}$ The inhibition of pancreatic amylase and $\beta$-glucosidase by phenolic compounds is very well documented. Exhaustive reviews can be found elsewhere. ${ }^{44,45}$ More recently, dietary fiber has been shown to inhibit enzymes involved in carbohydrate digestion. Guar gum is able to form a complex with $\alpha$-amylase that renders the enzyme inactive. ${ }^{46}$ Similar specific inhibitory effects have been reported for cellulose against $\alpha$-amylase ${ }^{47}$ and for fucoidan (sulfated polysaccharide from brown algae) against $\alpha$-amylase and $\beta$-glucosidase. ${ }^{48}$

\section{Protein digestion}

Analogous to how physical barriers affect the digestibility of starch and lipids, the structural barrier represented by the cell walls in plant foods may substantially reduce protein digestibility. However, compared with what is known about starch and lipid digestibility, much less is known about the effect of cellular integrity on protein digestibility, which calls for more research. An early report suggests that the in vitro digestibility of legume proteins can be as low as $50 \%$ when seeds are consumed whole. ${ }^{49} \mathrm{~A}$ more recent report confirms that, in almonds, a large portion of protein goes undigested and that the fraction of digested proteins increases when the food matrix is finely ground. ${ }^{8}$ Similar to the effect of milling on starch, the milling of cereals and legumes into flour would break down intact cell walls and increase the protein digestibility and, thus, the caloric content.

Proteins in food may occur in a variety of colloidal states and structural forms. The type of interaction between proteins as well as their structural organization plays a role in their digestibility. In plant food (eg, in intact grains or tubers), proteins occur as compact intracellular 
bodies of different size, shape, and composition. In other foods, proteins occur as fibrous structures (meat and fish), networks (bread and pasta), or micelles (dairy products) held together by covalent or noncovalent interactions. The nature and the extent of these interactions are very much affected by industrial and domestic processing, especially by heating, as examined in the next section. Differences in the shape and dimension of protein bodies may represent an important factor for the digestibility of proteins from cereals and legumes. A smart example was provided by studying the chemically induced sorghum mutant line, P721 opaque. ${ }^{50}$ The protein bodies of this line are unusual, as they appear irregularly shaped when viewed with transmission electron microscopy, with invaginations seen in the structure instead of the spherical shape typical of sorghum. This sorghum mutant line showed a higher protein digestibility, likely because the body surface exposed to proteases is greater than that of regular protein bodies. ${ }^{50}$ Protein gels obtained with different coagulants and structural properties may also show a different digestibility. In a model system of tofu made up of soy proteins, gelation obtained with covalent cross-links produced gels that are less digestible than those produced using an ionic gelation. ${ }^{51}$ Of course, proteins may be inherently resistant to digestion by pepsin and trypsin because of their specific primary structure or ternary/quaternary structure. A typical example is provided by phaseolin, the main storage protein of beans (Phaseolus vulgaris). ${ }^{52}$

Finally, a number of antinutritional factors may be present in plant-based foods that can hinder protein digestibility. Relatively high concentrations of antinutritional factors such as trypsin inhibitors, phytates, and hemagglutinins, may reduce the digestibility of legume proteins. ${ }^{15}$ Brassica vegetables contain glucosinolates and their breakdown products, isothiocyanates. Isothiocyanates are strongly electrophilic compounds able to react with amino acids, peptides, and proteins to form a vast array of derivatives that may decrease dietary protein digestibility and biological value. ${ }^{53}$ Polyphenols from different classes (flavonols, anthocyanins, proanthocyanidins, tannins) and different sources (berries, cocoa, tea) have been reported to have inhibitory activity against pancreatic proteases. ${ }^{54,55}$

\section{EFFECT OF PROCESSING ON DIGESTIBILITY OF MACRONUTRIENTS}

Food processing can substantially modify the structure and the composition of foods, thus affecting the digestion of macronutrients. ${ }^{56}$ Table 2. ${ }^{5,7-9,23,31-33,41,49,57-90}$ provides an overview of the effect of processing on macronutrient digestibility in different food categories.

The processes of grinding, milling, pureeing, and homogenization destroy the natural integrity of plant material. They increase the digestibility of macronutrients, as described for nuts, seeds, legumes, tubers, and cereals. The same applies for processes like extrusion or flaking, which employ both heating and particle size reduction. In a similar fashion, milk homogenization can improve lipid digestibility by reducing the size of lipid globules, ie, by increasing the total surface area that comes into contact with pancreatic lipase. ${ }^{83}$

Fermentation is another common preservation technique applied to both vegetal and animal foods. During fermentation, bacterial metabolism results in partial fermentation of dietary fiber (ie, the cell wall material), partial hydrolysis of macronutrients such as starch and proteins, and partial removal of antinutritional factors like phytates. Fermented products contain nutrients that are more available for absorption and thus may be more caloric than their unfermented counterparts. ${ }^{70,79}$

The next section focuses mainly on heating, which is universally applied to food products to make food microbiologically and to improve the sensory attributes of food. 


\section{Effect of heating on lipid digestibility}

Frying oils are one of the main contributors of fat intake in modern Western diets. Foods are fried not only at home but also by caterers, and many industrially prepared foods are also fried. Heat treatments have a very complex effect on lipid digestibility. During frying, the elevated temperatures $\left(>150^{\circ} \mathrm{C}\right)$ cause modifications in the triglyceride structure, mainly oxidation of the double bonds of unsaturated fatty acids and dimerization/polymerization of the oxidized intermediates. As a result, the polar fraction of frying oils/fats increases. There is some evidence that digestibility of fats/oils can decrease after severe heat treatment. Recently, it was reported that, in Wistar rats, the digestibility of thermally treated sunflower oil is up to $30 \%$ lower than that of fresh sunflower oil. ${ }^{88}$ It is still unclear whether the reduced bioavailability of frying oils derives from the poor absorption of polar oxidation products or whether those oxidation products affect the catalytic activity of pancreatic lipase. The digestibility of lipids may also be altered by heating as a consequence of the physical damage of the original food structure. Thermal treatment may cause cells to swell, thereby damaging the cell walls that act as structural barriers to lipid digestion. When fed to mice, cooked peanuts provided a significantly higher amount of energy compared with raw peanuts. ${ }^{57}$ It has been hypothesized that cooking may also denature oleosins, removing them from the surface of oil bodies and facilitating the access of lipase to lipids during subsequent gastric and small intestinal digestion. ${ }^{91}$ Increased lipid digestibility after roasting has been also reported for almonds. ${ }^{7}$

\section{Effect of heating on starch digestibility}

Thermal treatment of cereals and legumes by means of moist heat (boiling, steaming, etc) results in the gelatinization of starch granules, which increases starch digestibility enormously. The same holds true for parboiling of rice. ${ }^{62}$ Nongelatinized starch is unavailable to $\alpha$-amylase and is classified as type II resistant starch. Dry heating (oven baking, microwaving) also results in substantial gelatinization of starch if there is enough moisture around the globules, but it is less effective than moist heating. For instance, the amount of resistant starch is higher in roasted potatoes than in boiled potatoes. ${ }^{82}$ Thermal treatment also reduces the concentration of $\alpha$-amylase inhibitors, which further increases starch susceptibility to hydrolysis. Additional treatment after heating can further modify starch digestibility. The case of refrigerated boiled potatoes is interesting. Refrigeration after cooking leads to starch retrogradation and a decrease in starch digestibility. The application of a dehydration step after thermal treatment may increase starch digestibility, as occurs in the production of instant rice ${ }^{61}$ and after boiling of lentils. ${ }^{74}$ Interestingly, thermal treatment of starch in the presence of lipids may produce amylose-lipid complexes. ${ }^{92}$ Such complexes may be resistant to digestive amylases and are classified as type $\mathrm{V}$ resistant starches because they are resistant to digestion. ${ }^{93}$ Amylose-lipid and amylopectin-lipid complexes may also occur naturally in raw starchy foods. It is still not clear whether the formation of starch-lipid complexes in common starchy products rich with lipids has any nutritional significance.

In industrial processing, combined techniques are applied, which makes it difficult to predict the effects on digestibility. One example is extrusion cooking, which combines moist heat, pressure, and mechanical shearing to produce expanded, cooked products formed into specific shapes. The moist heating combined with the mechanical shearing results not only in starch gelatinization but also in the disruption of molecular interactions between starch molecules within the granule, which further increases starch digestibility. In general, extrusion results in an increase of starch digestibility, although the changes in digestibility depend on time-temperature combinations, force or pressure applied, and moisture levels. ${ }^{69}$

\section{Effect of heating on protein digestibility}


Heat treatment also affects protein digestibility. Thermal treatment destabilizes the tertiary structure of proteins, resulting in denaturation. Protein denaturation increases the susceptibility of proteins to digestive proteases by exposing hidden peptide bonds to enzymes, but the exposure of hydrophobic moieties favors protein aggregation, which, on the contrary, reduces the susceptibility of proteins to digestion. ${ }^{19,94}$ In general, the net effect of thermal treatment depends on the type of protein (primary structure, hydrophobic moieties), the severity of the heat treatment (time, temperature), and certain food properties (eg, protein content and water activity). The exposure of proteins to heat/alkali treatments can also induce racemization of L-amino acids to Damino acids and the formation of lysine-alanine, ${ }^{19}$ both of which may decrease the digestibility of proteins by interfering with the cleavage site for digestive proteases.

In several foods, a significant event occurs during heating: the reaction between free amino groups of proteins and reducing sugars, known as the Maillard reaction. There are 2 reasons why the binding of protein with sugar strongly reduces protein digestibility. First, lysine and arginine residues are blocked, so trypsin cannot hydrolyze the corresponding peptide bond. Second, the sugar moiety attached to 1 protein can crosslink to another protein chain, thus promoting the formation of high-molecular-weight protein aggregates called melanoproteins. ${ }^{95}$ Several examples of the formation of melanoproteins from caseins ${ }^{96}$ and from gluten ${ }^{97}$ have been reported. The effect of extensive aggregation and insolubilization of gluten proteins on calorie intake is particularly interesting. It has been reported that proteins in bread crust are less digestible than those present in bread crumb. ${ }^{68}$ During baking, bread crust is exposed to a considerably higher temperature $\left(>180^{\circ} \mathrm{C}\right)$ than bread crumb, and proteins in crust undergo greater denaturation, aggregation, and crosslink. However, a decrease in gluten digestibility of wheat bread crumb compared with the corresponding flour has also been reported. ${ }^{67}$ The protein digestibility of liquid infant formula is $13 \%$ lower than that of powdered infant formula, likely because of the higher content of Maillard reaction products, lysinoalanine, and oxidized products of sulfur amino acids in the former. ${ }^{87}$

In the absence of reducing sugars, a significant effect of heating on protein digestibility can be observed. The true ileal digestibility of cooked and raw egg protein amounted to $90.9 \pm 0.8 \%$ and $51.3 \pm 9.8 \%$, respectively. ${ }^{98}$ In another study, the amount of undigested protein was calculated as more than $30 \%$ for raw eggs in healthy individuals compared with approximately $5 \%$ in cooked egg protein meals. ${ }^{89}$ Alkaline/heat treatment had a significant negative effect on the true fecal digestibility of lactoalbumin (99\% of untreated vs $73 \%$ of alkali-/heat-treated) and soy protein isolate (96\% of untreated vs $68 \%$ of alkali-/heat-treated) in rats. ${ }^{94}$ Similarly, heating of casein at $180^{\circ} \mathrm{C}$ for 1 hour significantly decreased the digestibility of the protein and increased the degree of protein fermentation in the large intestine. ${ }^{99}$ However, the in vitro protein digestibility of pasteurized, ultrahigh-temperature-treated, and in-can sterilized milk was not different than that of raw milk. ${ }^{84}$ The protein digestibility of raw beef and beef cooked at $100^{\circ} \mathrm{C}$ for 10 and 30 minutes has also been investigated in an in vitro model of digestion. ${ }^{100}$ After 30 minutes of gastric phase digestion, the sarcomere structure of beef cooked for 30 minutes was still intact, whereas the sarcomere structure of raw beef and beef cooked for 10 minutes was lost. The authors hypothesized that "limit peptides" were formed during the cooking of the beef that cannot be further hydrolyzed to free amino acids. Boiling bovine meat at $100^{\circ} \mathrm{C}$ for 3 hours resulted in protein digestibility that was slightly less than that of raw meat (94.5\% vs $97.5 \%)$, but other cooking techniques, such as roasting, barbecuing, and grilling, had no effect. ${ }^{90,101}$

The effect of thermal processing on the digestibility of vegetal protein is further complicated by the fact that heating may also modify both the cell wall integrity and the fraction of fractured cells, resulting in an increase in the digestibility of proteins from plant-based foods consumed whole. The extrusion of seeds or legumes increases protein digestibility via the matrixdisrupting effect. ${ }^{58,78}$ Thermal treatment can also increase protein digestibility by inactivating naturally occurring trypsin inhibitors in, for example, legumes. 
To summarize, it is possible that mild thermal treatment increases protein digestibility as a result of protein denaturation, inactivation of protease inhibitors, and modification of cell wall integrity. On the other hand, intense thermal treatment, especially of food with low moisture content, decreases protein digestibility because of protein aggregation and blockage of sites used by trypsin for hydrolysis. During drying of pasta, for instance, protein digestibility may decrease because of aggregation of denaturated proteins. ${ }^{102}$

\section{CALORIE INTAKE FOR DIFFERENT DIETARY SCENARIOS}

When digestibility is considered to be the energy content claimed in the Nutrition Facts, then, recalling the example of almonds and chocolate-coated cookies proposed in Table 1, the energy content of almonds should be $460 \mathrm{kcal} / 100 \mathrm{~g}$, or $25 \%$ less caloric than the value calculated on the basis of the Atwater general system. ${ }^{10}$ This means that almonds are actually $12 \%$ less caloric than cookies. Obviously, this inaccuracy in calculating energy content can mislead consumers into buying cookies instead of the healthier and more nutritious almonds.

Considering the influence of food structure and processing on the availability of nutrients in the foods described above, the actual energy content measured may be significantly different in those diets in which foods of plant origin predominate, as already suggested by Merrill and Watt, ${ }^{15}$ but also in those diets in which highly processed foods are consumed. ${ }^{56}$ To estimate how large this effect can be, 3 diets were formulated and compared: a Western diet rich in highly processed foods, a diet based on the Mediterranean diet, and a vegan diet (Figure 2). These 3 diets have comparable macronutrient contents (see Table S1 in the Supporting Information online) and have been designed using foods for which data on nutrient bioavailability are already available in the literature (see Table S2 in the Supporting Information online). They differ in the amount of plant foods, especially plant foods that retain their physical integrity, in the following order: vegan diet $>$ Mediterranean diet $>$ Western diet. The energy content of each diet was calculated according to 3 different systems, outlined below.

System 1. The Atwater extensive general factor system, adopted by the European Union, regulates the provision of food information to consumers (Regulation EU 1169/2011) ${ }^{4}$ (thereafter referred to as GENERAL).

System 2. The Atwater specific factor system is based on the category-specific coefficients of digestibility for macronutrients proposed by Merrill and Watt ${ }^{15}$ (thereafter referred to as SPECIFIC).

System 3. An improved specific factor system uses food-specific coefficients of digestibility of macronutrients published in the scientific literature. The coefficients of digestibility were obtained from ileostomy studies and in vivo intervention studies (thereafter referred to as CORRECTED).

The results of these calculations are reported in Figure 3, while the details of the coefficients of digestibility, the references used, and an example of a calculation can be found in Appendices S1 and S2 in the Supporting Information online. The data clearly show an overestimation of energy content for the Mediterranean diet and an even greater overestimation for the vegan diet when the GENERAL and the SPECIFIC systems are applied, compared with the energy content obtained with the CORRECTED system. A slight underestimation of energy content obtained with the GENERAL system, but not with the SPECIFIC system, when compared with the energy content obtained with the CORRECTED system, was apparent for the Western diet.

This overestimation of the calorie content was slightly higher with the SPECIFIC system than with the GENERAL system. In the case of vegan diet, the overestimation of energy content was $8.3 \%$ with the SPECIFIC system and $6.9 \%$ with the GENERAL system. It was mainly 
attributable to the low digestibility of nuts, whole-grain pasta, bread, and legumes. In the case of the Mediterranean diet, the overestimation was 5.6\% and $4.2 \%$ for the SPECIFIC system and the GENERAL system, respectively, and was mainly attributable to the low digestibility of intact nuts and legumes. The greater overestimation resulting from the application of the SPECIFIC system compared with the GENERAL system stems from 2 aspects of the SPECIFIC system: (1) no distinction is made between dietary fiber and available carbohydrate, and (2) energy from carbohydrates is calculated by multiplying the total carbohydrates (determined by difference from the total weight once proteins, lipids, water and ash content has been determined) for the food- and nutrient-specific conversion factor. As a result, the overestimation when using the SPECIFIC system is somehow higher for high-fiber foods.

\section{EFFECT OF MIXED DIETS ON DIGESTIBILILTY OF MACRONUTRIENTS}

In the previous section, a so-called additive model was used to calculate the caloric content of mixed diets, ie, it was assumed that the caloric content of the entire diet is the sum of the caloric content of each meal component. This calculation does not consider that digestibility may decrease with the total amount of ingested macronutrients. This was shown for dietary proteins, for instance, in ileostomy patients. ${ }^{103}$ In addition, the bioavailability of dietary macronutrients may be limited by the simultaneous presence in the bolus/chyme of dietary components provided by other foods in a mixed meal. These dietary components may interfere with the digestion of macromolecules in the same way as described in Figure 1, panel C. For example, the digestibility of meat or fish proteins may be reduced by the presence of polyphenols, tannins, or dietary fiber from a side vegetable dish. The addition of $1 \mathrm{~g}$ of tea polyphenols (in the form of catechin) per day to a mouse's diet increases the amount of fecal energy from $1.6 \%$ to $5.8 \%$, mainly because of the loss of carbohydrates in the feces. ${ }^{104}$

The inclusion of dietary fiber also reduces the apparent digestibility of food macronutrients, reduces the metabolizable energy of food, and increases the energy content of feces. ${ }^{105-107}$ A recent study has compared the ileal excretion of energy from high-fiber rye-based meals and low-fiber wheat-based meals in ileostomy patients. Not surprisingly, around $10 \%$ of the gross energy content of the low-fiber meal was not digested and was excreted in the ileal fluid. As a result, this value jumps to more than $15 \%$ of the gross energy in the high-fiber meal. As much as $15 \%$ to $20 \%$ of the protein content of the meal was excreted, this percentage being higher in fiberrich diets. ${ }^{108}$ It is noteworthy that the extra dietary fiber was provided in the form of whole-grain crisp bread, so that the difference in metabolizable energy between the 2 diets could not be explained by the effect of encapsulation within intact structures but rather by the interaction between dietary fiber and other components of the meal. These examples show that the calculation of the true caloric content of a mixed meal should include factors for interactions between individual nutrients from different food items in the meal and that an interaction model should be used when calculating the caloric content of mixed diets. Considering that vegan and Mediterranean diets contain much more dietary fiber than the Western diet, it can be assumed that the differences in actual calorie intake are even greater than those calculated in Figure 3.

\section{CONCLUSION}

This review has highlighted the importance of considering the digestibility of macronutrients to calculate the energy content of foods and diets. The idea that all proteins, lipids, and carbohydrates present in food can be converted into calories in the human body is obviously misleading and has already been addressed by Atwater and other scholars over the last century during the development of suitable systems to calculate the energy content of food. However, recent 
studies in food science have highlighted the major role of the food matrix and processing conditions, especially heating conditions, in affecting the availability of macronutrients. In many foods, especially intact nuts, legumes, and cereals, the actual calorie intake is significantly different than that calculated using the procedures reported in the official regulations. Moreover, the composition and the structural differences of foods, even within the same category, can produce significant differences in the digestibility and, thus, the energy content. Here, it was shown that food-specific digestibility factors may generate substantial differences between the actual energy content of foods and that calculated with the Atwater extended and specific systems. This difference is relevant both at the level of single foods and at the level of diets. At the level of single foods, a more accurate estimation of the energy content of marketed foods can address the consumers' choices toward healthier food items (eg, whole foods) and can even open up possibilities for health claims to be incorporated in nutritional facts. When considering the whole diet, this discrepancy can be of marginal relevance in the frame of a varied diet (ie, Mediterranean diet), but it becomes particularly important for individuals who follow an strict dietary regimen. A diet with a very high intake of dietary fiber and whole grains or seeds, ie, plant-based foods, which retain most of their natural, intact physical integrity, provides a calorie intake significantly lower than that reported in the Nutrition Facts. This should also be considered during the development of healthy foods for the management and prevention of overweight and obesity.

\section{Supporting Information}

The following Supporting Information is available through the online version of this article at the publisher's website:

Appendix S1 Calculation of the caloric content of diets

Appendix S2 Example: calories calculation for dry beans

Table S1 Macronutrient composition of the three diets

Table S2 Food composition of the three diets

\section{Acknowledgements}

Author contributions: All the authors participated in the design of the manuscript and in its revision. All the authors approved the final manuscript.

Funding and sponsorship: No external funds supported this work.

Declaration of interest: The authors have no relevant interests to declare.

\section{References}

1. Drichoutis AC, Lazaridis P, Nayga RM Jr. Consumers' use of nutritional labels: a review of research studies and issues. J Acad Mark Sci. 2006; 1. [TQ1]

2. Carmody RN, Weintraub GS, Wrangham RW. Energetic consequences of thermal and nonthermal food processing. Proc Natl Acad Sci USA. 2011;108:19199-19203. [PMC][10.1073/pnas.1112128108] [22065771][Mismatch] 
3. European Institute of Oncology. Food Composition Database for Epidemiological Studies in Italy (Banca Dati di Composizione degli Alimenti per Studi Epidemiologici in Italia - BDA), 2015. (http://www.bda-ieo.it. Accessed December 16, 2016).

4. Parliament E. Regulation (EU) 1169/2011 of the European Parliament and of the Council of 25 October 2011 on the provision of food information to consumers. Off $\mathrm{J}$ Eur Commun. 2011;L304:18.

5. Ellis PR, Kendall CW, Ren Y, et al. Role of cell walls in the bioaccessibility of lipids in almond seeds. Am J Clin Nutr. 2004;80:604-613.

6. Grundy MML, Grassby T, Mandalari G, et al. Effect of mastication on lipid bioaccessibility of almonds in a randomized human study and its implications for digestion kinetics, metabolizable energy, and postprandial lipemia. Am J Clin Nutr. 2015;101:25-33. [CrossRef][10.3945/ajen.114.088328]

7. Grundy MML, Wilde PJ, Butterworth PJ, et al. Impact of cell wall encapsulation of almonds on in vitro duodenal lipolysis. Food Chem. 2015;185:405-412. [PMC][10.1016/j.foodchem.2015.04.013] [25952886]

8. Mandalari G, Faulks RM, Rich GT, et al. Release of protein, lipid, and vitamin E from almond seeds during digestion. J Agric Food Chem. 2008;56:3409-3416. [PMC][10.1021/jf073393v] [18416553]

9. Cassady BA, Hollis JH, Fulford AD, et al. Mastication of almonds: effects of lipid bioaccessibility, appetite, and hormone response. Am J Clin Nutr. 2009;89:794-800. [PMC][10.3945/ajcn.2008.26669] [19144727]

10. Novotny JA, Gebauer SK, Baer DJ. Discrepancy between the Atwater factor predicted and empirically measured energy values of almonds in human diets. Am J Clin Nutr. 2012;96:296-301. [PMC][10.3945/ajcn.112.035782] [22760558]

11 Zou ML, Moughan PJ, Awati A, et al. Accuracy of the Atwater factors and related food energy conversion factors with low-fat, high-fiber diets when energy intake is reduced spontaneously. Am J Clin Nutr. 2007;86:1649-1656. [PMC][18065582]

12. Food and Agriculture Organization of the United Nations. Food Energy-Methods of Analysis and Conversion Factors. Rome, Italy: Food and Agriculture Organization of the United Nation; 2003. FAO Food and Nutrition Paper 77.

13. Atwater WO, Benedict FG. Experiments on the Metabolism of Matter and Energy in the Human Body, 1898-1900. Washington, DC: US Government Printing Office; 1902. US Department of Agriculture, Office of Experiment Stations-Bulletin no. 109.

14. Secretariat of the Codex Alimentarius, Joint Food and Agriculture Organization of the United Nations/World Health Organization Food Standards Programme. Codex Alimentarius: Guidelines on Nutrition Labelling CAC/GL 2-1985 as Last Amended 2010. Rome, Italy: Food and Agriculture Organization; 2010.

15. Merrill A, Watt B. Energy Value of Foods-Basis and Derivation. Washington, DC: Agricultural Research Service, US Department of Agriculture; 1973. Agriculture Handbook no. 74. 
16. Livesey G. A perspective on food energy standards for nutrition labelling. $\mathrm{Br} J$ Nutr. 2001;85:271-287. [PMC][11299073]

17. U.S. Food and Drug Administration. Title 21 Code of Federal Regulations. U.S. Government Printing Office, Washington DC; 1998

18. Government of Canada: Food and drug regulations C.R.C., c.870, Curr 25 August 2013.

19. Gilani GS, Cockell KA, Sepehr E. Effects of antinutritional factors on protein digestibility and amino acid availability in foods. J AOAC Int. 2005;88:967-987. [PMC][16001874]

20. Singh H, Ye A, Horne D. Structuring food emulsions in the gastrointestinal tract to modify lipid digestion. Prog Lipid Res. 2009;48:92-100. [PMC][10.1016/j.plipres.2008.12.001] [19116160]

21. Grassby T, Picout DR, Mandalari G, et al. Modelling of nutrient bioaccessibility in almond seeds based on the fracture properties of their cell walls. Food Funct. 2014;5:3096-3106. [CrossRef][10.1039/C4FO00659C]

22. Baer D, Gebauer S, Novotny J. Atwater factors overestimate the calorie content of walnuts (371.1). FASEB J. 2014;28:371.

23. Traoret CJ, Lokko P, Cruz ACRF, et al. Peanut digestion and energy balance. Int J Obes (Lond). 2007;32:322-328. [PMC][10.1038/sj.ijo.0803735] [17912269][Mismatch]

24. Baer DJ, Gebauer SK, Novotny JA. Measured energy value of pistachios in the human diet. Br J Nutr. 2012;107:120-125. [PMC][10.1017/S0007114511002649] [21733319]

25. Lamothe S, Corbeil MM, Turgeon SL, et al. Influence of cheese matrix on lipid digestion in a simulated gastro-intestinal environment. Food Funct. 2012;3:724-731. [CrossRef][10.1039/c2fo10256k]

26. Renner E. Nutritional aspects of cheese. In: Fox PF, ed. Cheese: Chemistry, Physics and Microbiology. Volume 1: General Aspects. 2nd ed. Boston, MA: Springer; 1993:557-579.

27. Thorning TK, Raben A, Bendsen NT, et al. Importance of the fat content within the cheesematrix for blood lipid profile, faecal fat excretion, and gut microbiome in growing pigs. Int Dairy $J$. 2016;61:67-75. [CrossRef][10.1016/j.idairy].2016.04.006]

28. Thorning TK, Raziani F, Bendsen NT, et al. Diets with high-fat cheese, high-fat meat, or carbohydrate on cardiovascular risk markers in overweight postmenopausal women: a randomized crossover trial. Am J Clin Nutr. 2015;102:573-581. [PMC][10.3945/ajcn.115.109116] [26178720]

29. Christensen R, Lorenzen JK, Svith CR, et al. Effect of calcium from dairy and dietary supplements on faecal fat excretion: a meta-analysis of randomized controlled trials. Obes Rev. 2009;10:475-486. [CrossRef][10.1111/j.1467-789X.2009.00599.x][Mismatch]

30. Bravo LA, Mañas E, Saura-Calixto F. Dietary non-extractable condensed tannins as indigestible compounds: effects on faecal weight, and protein and fat excretion. J Sci Food Agric. 1993;63:63-68. [CrossRef][10.1002/jsfa.2740630111] 
31. Edwards CH, Warren FJ, Campbell GM, et al. A study of starch gelatinisation behaviour in hydrothermally-processed plant food tissues and implications for in vitro digestibility. Food Funct. 2015;6:3634-3641. [CrossRef][10.1039/C5FO00754B]

32. Livesey G, Wilkinson JA, Roe M, et al. Influence of the physical form of barley grain on the digestion of its starch in the human small intestine and implications for health. Am J Clin Nutr. 1995;61:75-81. [PMC][7825542]

33. Muir JG, Odea K. Measurement of resistant starch-factors affecting the amount of starch escaping digestion in vitro. Am J Clin Nutr. 1992;56:123-127. [PMC][1609748][Mismatch]

34. Woolnough JW, Monro JA, Brennan CS, et al. Simulating human carbohydrate digestion in vitro: a review of methods and the need for standardisation. Int J Food Sci Technol. 2008;43:22452256. [CrossRef][10.1111/j.1365-2621.2008.01862.x]

35. Jenkins DJ, Thorne MJ, Wolever TM, et al. The effect of starch-protein interaction in wheat on the glycemic response and rate of in vitro digestion. Am J Clin Nutr. 1987;45:946-951. [PMC][3578096]

36. Wolever TMS, Cohen Z, Thompson LU, et al. Ileal loss of available carbohydrate in mancomparison of a breath hydrogen method with direct measurement using a human ileostomy model. Am J Gastroenterol. 1986;81:115-122.

37. Bhattarai RR, Dhital S, Gidley MJ. Interactions among macronutrients in wheat flour determine their enzymic susceptibility. Food Hydrocoll. 2016;61:415-425. [CrossRef][10.1016/j.foodhyd.2016.05.026]

38. Fardet A, Hoebler C, Baldwin PM, et al. Involvement of the protein network in the in vitro degradation of starch from spaghetti and lasagne: a microscopic and enzymic study. J Cereal Sci. 1998;27:133-145. [CrossRef][10.1006/jcrs.1997.0157]

39. Zou W, Sissons M, Gidley MJ, et al. Combined techniques for characterising pasta structure reveals how the gluten network slows enzymic digestion rate. Food Chem. 2015;188:559-568. [PMC][10.1016/j.foodchem.2015.05.032] [26041231]

40. Goñi I, García-Diz L, Mañas E, et al. Analysis of resistant starch: a method for foods and food products. Food Chem. 1996;56:445-449. [CrossRef][10.1016/0308-8146(95)00222-7]

41. Englyst HN, Cummings JH. Digestion of polysaccharides of potato in the small intestine of man. Am J Clin Nutr. 1987;45:423-431. [PMC][3812341]

42. Namratha J, Asna U, Prasad NN. Effect of storage on resistant starch content of processed ready-to-eat foods. Food Chem. 2002;79:395-400. [CrossRef][10.1016/S0308-8146(02)00210-8]

43. Buonocore V, Silano V. Biochemical, nutritional and toxicological aspects of alpha-amylase inhibitors from plant foods. In: Friedman M, ed. Nutritional and Toxicological Significance of Enzyme Inhibitors in Foods. Boston, MA: Springer; 1986:483-507.

44. $\mathrm{Xu} \mathrm{W}$, Shao $\mathrm{R}$, Xiao J. Is there consistency between the binding affinity and inhibitory potential of natural polyphenols as $\alpha$-amylase inhibitors? Crit Rev Food Sci Nutr. 2016;56:16301639. [CrossRef][10.1080/10408398.2013.793652] 
45. Xiao J, Kai G, Yamamoto K, et al. Advance in dietary polyphenols as $\alpha$-glucosidases inhibitors: a review on structure-activity relationship aspect. Crit Rev Food Sci Nutr. 2013;53:818836. [CrossRef][10.1080/10408398.2011.561379]

46. Slaughter SL, Ellis PR, Jackson EC, et al. The effect of guar galactomannan and water availability during hydrothermal processing on the hydrolysis of starch catalysed by pancreatic $\alpha$ amylase. Biochim Biophys Acta. 2002;1571:55-63. [PMC][12031290]

47. Dhital S, Gidley MJ, Warren FJ. Inhibition of $\alpha$-amylase activity by cellulose: kinetic analysis and nutritional implications. Carbohydr Polym. 2015;123:305-312. [CrossRef][10.1016/j.carbpol.2015.01.039][Mismatch]

48. Kim KT, Rioux LE, Turgeon SL. Alpha-amylase and alpha-glucosidase inhibition is differentially modulated by fucoidan obtained from Fucus vesiculosus and Ascophyllum nodosum. Phytochemistry. 2014;98:27-33. [CrossRef][10.1016/j.phytochem.2013.12.003]

49. Melito C, Tovar J. Cell-walls limit in vitro protein digestibility in processed legume seeds. Food Chem. 1995;53:305-307. [CrossRef][10.1016/0308-8146(95)93937-M]

50. Oria MP, Hamaker BR, Axtell JD, et al. A highly digestible sorghum mutant cultivar exhibits a unique folded structure of endosperm protein bodies. Proc Natl Acad Sci USA. 2000;97:50655070. [PMC][10.1073/pnas.080076297] [10792028]

51. Rui X, Fu Y, Zhang Q, et al. A comparison study of bioaccessibility of soy protein gel induced by magnesium chloride, glucono- $\delta$-lactone and microbial transglutaminase. $L W T$ Food $S c i$ Technol. 2016;71:234-242. [CrossRef][10.1016/j.lwt.2016.03.032]

52. Jivotovskaya AV, Senyuk VI, Rotari VI, et al. Proteolysis of phaseolin in relation to its structure. J Agric Food Chem. 1996;44:3768-3772. [CrossRef][10.1021/jf960129l]

53. Capuano E, Dekker M, Verkerk R, et al. Food as pharma? The case of glucosinolates. Curr Pharm Des. 2017;23:1-25. [CrossRef][Mismatch]

54. Stojadinovic M, Radosavljevic J, Ognjenovic J, et al. Binding affinity between dietary polyphenols and $\beta$-lactoglobulin negatively correlates with the protein susceptibility to digestion and total antioxidant activity of complexes formed. Food Chem. 2013;136:1263-1271.

55. McDougall GJ, Kulkarni NN, Stewart D. Current developments on the inhibitory effects of berry polyphenols on digestive enzymes. Biofactors. 2008;34:73-80. [CrossRef][10.1002/biof.5520340108]

56. Pellegrini N, Fogliano V. Cooking, industrial processing and caloric density of foods. Curr Opin Food Sci. 2017;14:98-102. [CrossRef][10.1016/j.cofs.2017.02.006]

57. Groopman EE, Carmody RN, Wrangham RW. Cooking increases net energy gain from a lipid-rich food. Am J Phys Anthropol. 2015;156:11-18. [PMC][10.1002/ajpa.22622] [25293786]

58 Wang Y, Li D, Wang L-J, et al. Optimization of extrusion of flaxseeds for in vitro protein digestibility analysis using response surface methodology. $J$ Food Eng. 2008;85:59-64. [CrossRef][10.1016/j.jfoodeng.2007.06.033] 
59. Xue Q, Newman RK, Newman CW. Effects of heat treatment of barley starches on in vitro digestibility and glucose responses in rats. Cereal Chem. 1996;73:588-592.

60. Ovando-Martínez M, Whitney K, Reuhs BL, et al. Effect of hydrothermal treatment on physicochemical and digestibility properties of oat starch. Food Res Int. 2013;52:17-25. [CrossRef][10.1016/j.foodres.2013.02.035]

61. Rewthong O, Soponronnarit S, Taechapairoj C, et al. Effects of cooking, drying and pretreatment methods on texture and starch digestibility of instant rice. J Food Eng. 2011;103:258264. [CrossRef][10.1016/j.jfoodeng.2010.10.022]

62. Gunaratne A, Kao W, Ratnayaka J, et al. Effect of parboiling on the formation of resistant starch, digestibility and functional properties of rice flour from different varieties grown in Sri Lanka. J Sci Food Agric. 2013;93:2723-2729. [PMC][10.1002/jsfa.6091] [23553043]

63. Sayago-Ayerdi SG, Tovar J, Zamora-Gasga VM, et al. Starch digestibility and predicted glycaemic index (pGI) in starchy foods consumed in Mexico. Starke. 2014;66:91-101. [CrossRef][10.1002/star.201200206][Mismatch]

64. Protonotariou S, Mandala I, Rosell CM. Jet milling effect on functionality, quality and in vitro digestibility of whole wheat flour and bread. Food Bioprocess Technol. 2015;8:1319-1329. [CrossRef][10.1007/s11947-015-1494-z]

65. Edwards CH, Grundy MML, Grassby T, et al. Manipulation of starch bioaccessibility in wheat endosperm to regulate starch digestion, postprandial glycemia, insulinemia, and gut hormone responses: a randomized controlled trial in healthy ileostomy participants. Am J Clin Nutr. 2015;102:791-800. [CrossRef][10.3945/ajcn.114.106203]

66. Tamura M, Singh J, Kaur L, et al. Impact of the degree of cooking on starch digestibility of rice-an in vitro study. Food Chem. 2016;191:98-104. [CrossRef][10.1016/j.foodchem.2015.03.127]

67. Smith F, Pan X, Bellido V, et al. Digestibility of gluten proteins is reduced by baking and enhanced by starch digestion. Mol Nutr Food Res. 2015;59:2034-2043. [PMC][10.1002/mnfr.201500262] [26202208]

68. Pasini G, Simonato B, Giannattasio M, et al. Modifications of wheat flour proteins during in vitro digestion of bread dough, crumb, and crust: an electrophoretic and immunological study. $J$ Agric Food Chem. 2001;49:2254-2261. [CrossRef][10.1021/jf0014260]

69. Robin F, Heindel C, Pineau N, et al. Effect of maize type and extrusion-cooking conditions on starch digestibility profiles. Int J Food Sci Technol. 2016;51:1319-1326. [CrossRef][10.1111/ijfs.13098]

70. Chavan UD, Chavan JK, Kadam SS. Effect of fermentation on soluble proteins and in vitro protein digestibility of sorghum, green gram and sorghum-green gram blends. J Food Sci. 1988;53:1574-1575. [CrossRef][10.1111/j.1365-2621.1988.tb09329.x]

71. Eyaru R, Shrestha AK, Arcot J. Effect of various processing techniques on digestibility of starch in red kidney bean (Phaseolus vulgaris) and two varieties of peas (Pisum sativum). Food Res Int. 2009;42:956-962. [CrossRef][10.1016/j.foodres.2009.06.007] 
72. Morinaga K. Effects of crush and heat on the digestibility of protein and the activity of trypsin-inhibitor of the parched soybean flour. J Jpn Soc Food Sci Technol. 1997;44:219-225. [CrossRef][10.3136/nskkk.44.219][Mismatch]

73. Hawkins A, Johnson SK. In vitro carbohydrate digestibility of whole-chickpea and chickpea bread products. Int J Food Sci Nutr. 2005;56:147-155. [PMC][10.1080/09637480500103920] [16009629]

74. Aguilera Y, Esteban RM, Benitez V, et al. Starch, functional properties, and microstructural characteristics in chickpea and lentil as affected by thermal processing. J Agric Food Chem. 2009;57:10682-10688. [CrossRef][10.1021/jf902042r][Mismatch]

75. Berg T, Singh J, Hardacre A, et al. The role of cotyledon cell structure during in vitro digestion of starch in navy beans. Carbohydr Polym. 2012;87:1678-1688. [CrossRef][10.1016/j.carbpol.2011.09.075]

76. Chacko A, Cummings JH. Nitrogen losses from the human small bowel: obligatory losses and the effect of physical form of food. Gut. 1988;29:809-815. [PMC][2838402]

77. Simsek S, Herken EN, Ovando-Martinez M. Chemical composition, nutritional value and in vitro starch digestibility of roasted chickpeas. J Sci Food Agric. 2016;96:2896-2905. [PMC][10.1002/jsfa.7461] [26374493]

78. Abd El-Hady EA, Habiba RA. Effect of soaking and extrusion conditions on antinutrients and protein digestibility of legume seeds. LWT Food Sci Technol. 2003;36:285-293. [CrossRef][10.1016/S0023-6438(02)00217-7]

79. Kiers JL, Van Laeken AEA, Rombouts FM, et al. In vitro digestibility of Bacillus fermented soya bean. Int J Food Microbiol. 2000;60:163-169. [PMC][11016606]

80. Dupuis JH, Lu ZH, Yada RY, et al. The effect of thermal processing and storage on the physicochemical properties and in vitro digestibility of potatoes. Int J Food Sci Technol. 2016;51:2233-2241. [CrossRef][10.1111/ijfs.13184]

81. Nayak B, Berrios JD, Tang J. Impact of food processing on the glycemic index (GI) of potato products. Food Res Int. 2014;56:35-46. [CrossRef][10.1016/j.foodres.2013.12.020]

82. García-Alonso A, Goñi I. Effect of processing on potato starch: in vitro availability and glycaemic index. Nahrung. 2000;44:19-22. [PMC][10.1002/(SICI)1521-3803(20000101)44: 1\&lt;19:: AID-FOOD19\&gt;3.0.CO;2-E] [10702994]

83. Gallier S, Acton D, Garg M, et al. Natural and processed milk and oil body emulsions: bioavailability, bioaccessibility and functionality. Food Struct. 2016;13:13-23

84. Wada Y, Lonnerdal B. Effects of different industrial heating processes of milk on sitespecific protein modifications and their relationship to in vitro and in vivo digestibility. $J$ Agric Food Chem. 2014;62:4175-4185. [CrossRef][10.1021/jf501617s][Mismatch]

85. Fang XX, Rioux LE, Labrie S, et al. Disintegration and nutrients release from cheese with different textural properties during in vitro digestion. Food Res Int. 2016;88:276-283. [CrossRef][10.1016/j.foodres.2016.04.008] 
86. Lopez C, Le Ruyet P, Quiblier JP. Milk fat in ripened cheeses: effect of its composition, its suprastructure and other components of the matrix on its digestion, and metabolic consequences. Sci Aliment. 2010;29:69-87. [Mismatch]

87. Sarwar G, Peace RW, Botting HG. Differences in protein digestibility and quality of liquid concentrate and powder forms of milk-based infant formulas fed to rats. Am J Clin Nutr. 1989;49:806-813. [PMC][2497631]

88. David RO, Sanchez-Muniz FJ, Bastida S, et al. Gastric emptying and short-term digestibility of thermally oxidized sunflower oil used for frying in fasted and nonfasted rats. J Agric Food Chem. 2010;58:9242-9248. [CrossRef][10.1021/jf101715g][Mismatch]

89. Evenepoel P, Claus D, Geypens B, et al. Amount and fate of egg protein escaping assimilation in the small intestine of humans. Am J Physiol. 1999;277(5 pt 1):G935-G943. [PMC][10564098][Mismatch]

90. Oberli M, Lan A, Khodorova N, et al. Compared with raw bovine meat, boiling but not grilling, barbecuing, or roasting decreases protein digestibility without any major consequences for intestinal mucosa in rats, although the daily ingestion of bovine meat induces histologic modifications in the colon. $J$ Nutr. 2016;146:1506-1513. [CrossRef][10.3945/jn.116.230839]

91. Gallier S, Singh H. Behavior of almond oil bodies during in vitro gastric and intestinal digestion. Food Funct. 2012;3:547-555. [CrossRef][10.1039/c2fo10259e]

92. Thachil MT, Chouksey MK, Gudipati V. Amylose-lipid complex formation during extrusion cooking: effect of added lipid type and amylose level on corn-based puffed snacks. Int J Food Sci Technol. 2014;49:309-316. [CrossRef][10.1111/ijfs.12333]

93. Holm J, Björck I, Ostrowska S, et al. Digestibility of amylose-lipid complexes in-vitro and in-vivo. Starke. 1983;35:294-297. [CrossRef][10.1002/star.19830350902]

94. Sarwar G, L’Abbé MR, Trick K, et al. Influence of feeding alkaline/heat processed proteins on growth and protein and mineral status of rats. In: Jackson LS, Knize MG, Morgan JN, eds. Impact of Processing on Food Safety. Boston, MA: Springer; 1999:161-177.

95. Morales FJ, Somoza V, Fogliano V. Physiological relevance of dietary melanoidins. Amino Acids. 2012;42:1097-1109. [PMC][10.1007/s00726-010-0774-1] [20949365]

96. Hofmann T. Studies on melanoidin-type colorants generated from the Maillard reaction of protein-bound lysine and furan-2-carboxaldehyde-chemical characterisation of a red coloured domaine. Eur Food Res Technol. 1998;206:251-258. [CrossRef][10.1007/s002170050253][Mismatch]

97. Fogliano V, Monti SM, Musella T, et al. Formation of coloured Maillard reaction products in a gluten-glucose model system. Food Chem. 1999;66:293-299. [CrossRef][10.1016/S03088146(99)00058-8]

98. Evenepoel P, Geypens B, Luypaerts A, et al. Digestibility of cooked and raw egg protein in humans as assessed by stable isotope techniques. $J$ Nutr. 1998;128:1716-1722. [PMC][9772141] 
99. Corpet DE, Yin Y, Zhang XM, et al. Colonic protein fermentation and promotion of colon carcinogenesis by thermolyzed casein. Nutr Cancer. 1995;23:271-281. [CrossRef][10.1080/01635589509514381]

100. Kaur L, Maudens E, Haisman DR, et al. Microstructure and protein digestibility of beef: the effect of cooking conditions as used in stews and curries. LWT Food Sci Technol. 2014;55:612-620. [CrossRef][10.1016/j.lwt.2013.09.023]

101. Oberli M, Marsset-Baglieri A, Airinei G, et al. High true ileal digestibility but not postprandial utilization of nitrogen from bovine meat protein in humans is moderately decreased by high-temperature, long-duration cooking. $J \quad$ Nutr. 2015;145:2221-2228. [CrossRef][10.3945/jn.115.216838]

102. Oliviero T, Fogliano V. Food design strategies to increase vegetable intake: the case of vegetable enriched pasta. Trends Food Sci Tech. 2016;51:58-64. [CrossRef][10.1016/j.tifs.2016.03.008]

103. Silvester KR, Cummings JH. Does digestibility of meat protein help explain large bowel cancer risk? Nutr Cancer. 1995;24:279-288. [PMC][10.1080/01635589509514417] [8610047]

104. Unno T, Osada C, Motoo Y, et al. Dietary tea catechins increase fecal energy in rats. $J$ Nutr Sci Vitaminol (Tokyo). 2009;55:447-451. [PMC][19926934]

105. Baer DJ, Rumpler WV, Miles CW, et al. Dietary fiber decreases the metabolizable energy content and nutrient digestibility of mixed diets fed to humans. J Nutr. 1997;127:579-586.

106. Southgate DAT. Fibre and the other unavailable carbohydrates and their effects on the energy value of the diet. Proc Nutr Soc. 1973;32:131-136. [CrossRef][10.1079/PNS19730030]

107. Miles CW, Kelsay JL, Wong NP. Effect of dietary fiber on the metabolizable energy of human diets. J Nutr. 1988;118:1075-1081. doi:10.3402/fnr.v57i0.18519 [PMC][2843615]

108. Isaksson H, Landberg R, Sundberg B, et al. High-fiber rye diet increases ileal excretion of energy and macronutrients compared with low-fiber wheat diet independent of meal frequency in ileostomy subjects. Food Nutr Res. 2013;57. doi:10.3402/fnr.v57i0.18519 [CrossRef][10.3402/fnr.v57i0.18519] 
Figure 1 Overview of factors that may affect the digestion of macronutrients.

(A) Structural properties of foods are of primary importance for the digestion of macronutrients. In plant foods, macronutrients may partly escape digestion when encapsulated within (1) intact cells or (2) biopolymer networks. (B) Different microstructures in macronutrients have different degrees of resistance to hydrolysis by digestive enzymes. (1) Starch in plants is found as globules of different size and shape. After gelatinization, the starch globules swell and lose part of their crystallinity. (2) Lipids in food are found as bodies (in plants) or globules (in milk or other emulsions) of different size. Moreover, different types of surfactants can stabilize natural or process-induced emulsion (represented here by globule coatings of different thickness and color). (3) Proteins in food are also found as a variety of structures, from protein bodies of different size, shape, and organization, to globular molecules, random coils, fibrous aggregates, or networks. (C) Digestion of macromolecules may be affected by dietary components that complex and precipitate enzymes, substrates, or hydrolysis products by (1) dietary components that inhibit the catalytic activity of enzymes ([2] here, only competitive inhibition is displayed for clarity of representation) or by (3) dietary components that change either (a) the rheological properties of the digesta by, for instance, increasing its viscosity or (b) the colloidal state of the digesta, for instance, by modifying the aggregation of emulsified lipids.

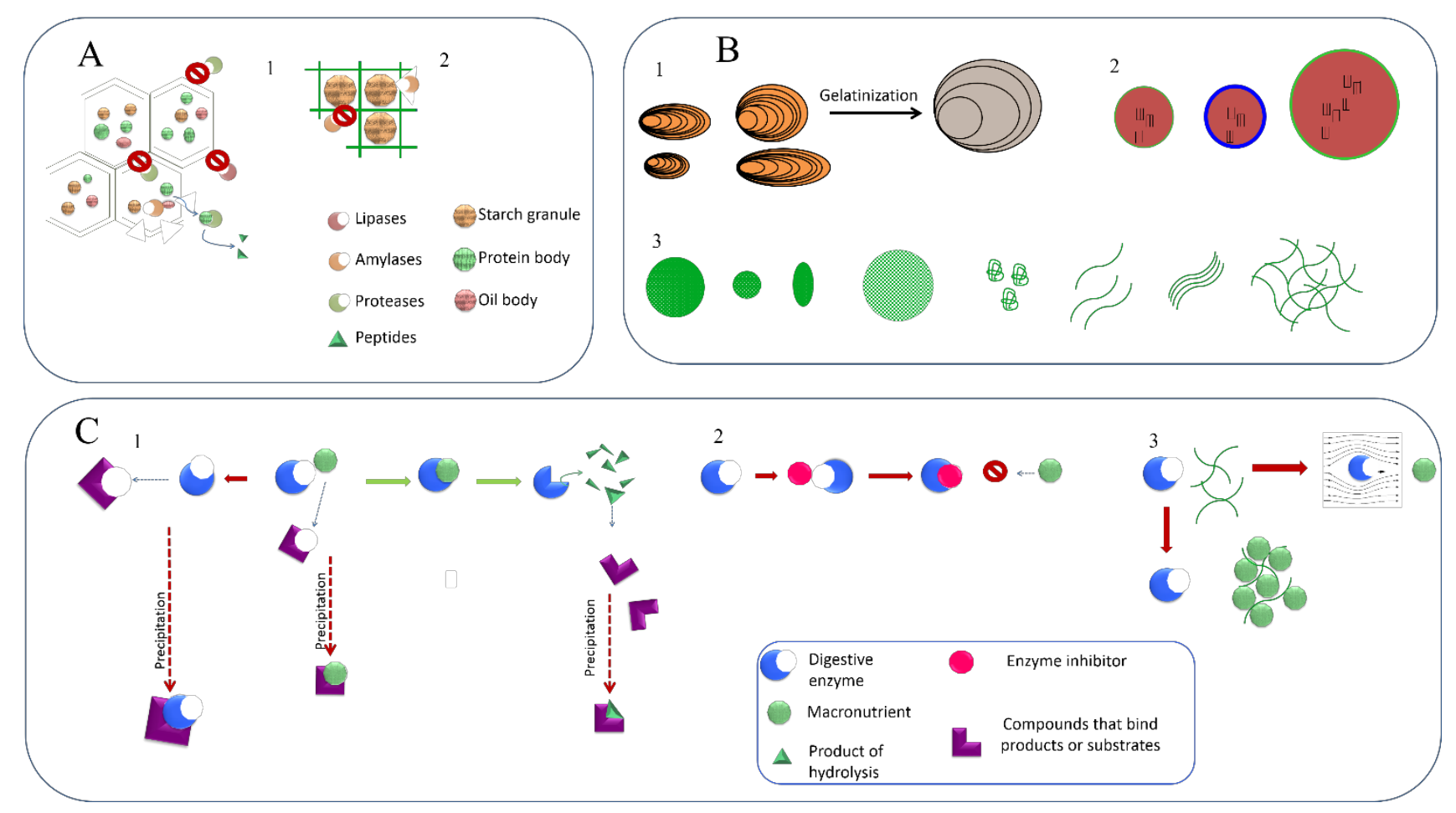


Figure 2 Visual representation of the composition of the 3 diets. Details on the composition of the diets are provided in the Supporting Information online (Table S1 and table S2).

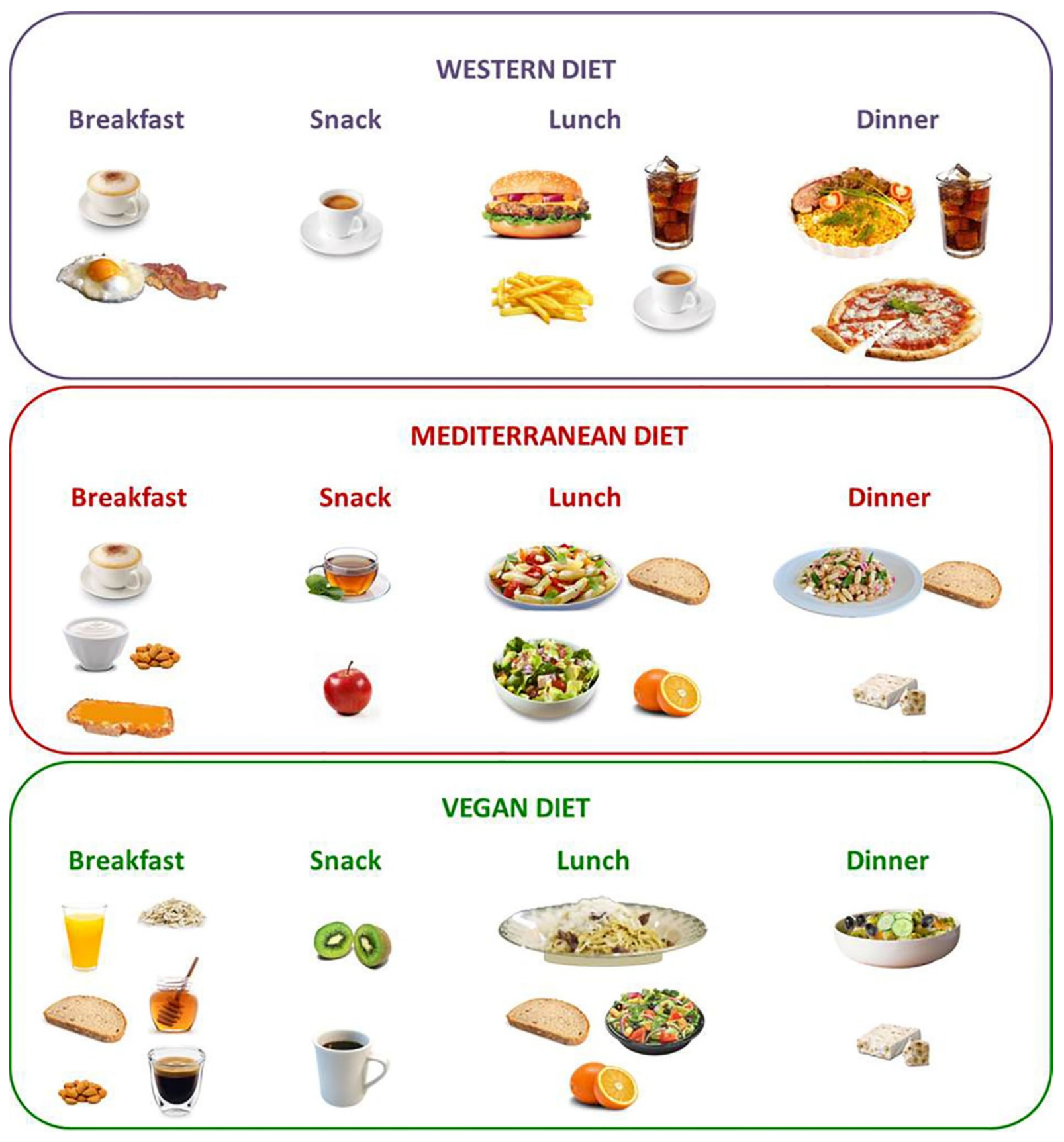


Figure 3 Energy content of the 3 diets as calculated by the 3 energy calculation systems, showing the overestimation that occurs with the GENERAL and SPECIFIC systems compared with the CORRECTED system.

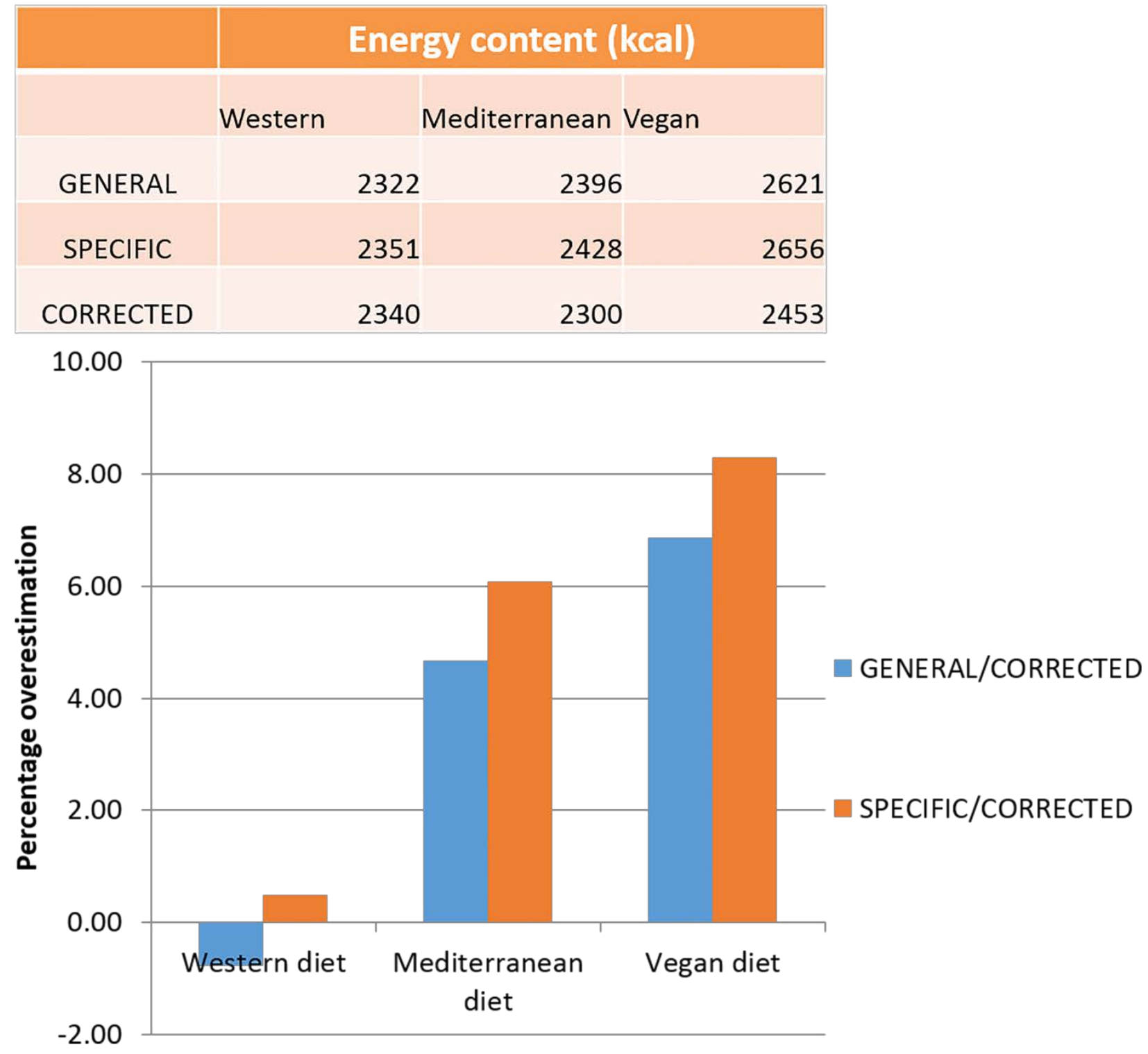


Table 1 Macronutrient content and energy value in dry roasted almonds and chocolate-coated cookies $^{\mathbf{a}}$

\begin{tabular}{|l|l|l|l|}
\hline Nutrient & Unit & $\begin{array}{l}\text { Value per 100 g } \\
\text { of almonds, dry } \\
\text { roasted }^{b}\end{array}$ & $\begin{array}{l}\text { Value per 100 g of } \\
\text { cookies, coated } \\
\text { with chocolate }^{\text {b }}\end{array}$ \\
\hline Water & grams & 5.1 & 2.2 \\
\hline Energy & kilocalories & 629.5 & 546.6 \\
\hline Protein & grams & 22.0 & 5.7 \\
\hline Total lipids & grams & 55.3 & 27.6 \\
\hline Saturated lipids & grams & 4.6 & 5.6 \\
\hline Total carbohydrates & grams & 4.6 & 67.4 \\
\hline Sugars & grams & 3.7 & 43.4 \\
\hline Total dietary fiber & grams & 12.7 & 2.9 \\
\hline
\end{tabular}

a Data adapted from the database of European Institute of Oncology, Food composition database for epidemiological studies in Italy (http://www.bda-ieo.it Published 2015. Accessed December 16, 2016). ${ }^{3}$

${ }^{\mathrm{b}}$ Energy value (in kilocalories) calculated using the energy factors provided in Regulation EU $1169 / 2011.4$ 
Table 2 Effect of processing on the digestibility of starch, proteins, and lipids in the major food categories

\begin{tabular}{|c|c|c|c|c|}
\hline $\begin{array}{l}\text { Food } \\
\text { category }\end{array}$ & Type of processing & $\begin{array}{l}\text { Food } \\
\text { product }\end{array}$ & $\begin{array}{l}\text { Effect on } \\
\text { macronutrient } \\
\text { digestibility }\end{array}$ & References \\
\hline \multirow[t]{5}{*}{ Nuts/seeds } & Milling & Almonds & Increase all & $\begin{array}{l}\text { Ellis et al (2004), }{ }^{5} \text { Grundy et al } \\
\text { (2015), }{ }^{7} \text { Mandalari et al (2008), } \\
\text { Cassady et al (2009) }\end{array}$ \\
\hline & Milling & Peanuts & Increases lipids & Traoret et al (2007) ${ }^{23}$ \\
\hline & Roasting & Almonds & Increases lipids & Grundy et al (2015) ${ }^{7}$ \\
\hline & Roasting & Peanuts & $\begin{array}{l}\text { Increases lipids } \\
\text { and overall } \\
\text { energy }\end{array}$ & Groopman et al (2015) $)^{57}$ \\
\hline & Extrusion & Flaxseed & $\begin{array}{l}\text { Increases } \\
\text { proteins }\end{array}$ & Wang et al (2008) ${ }^{58}$ \\
\hline \multirow[t]{13}{*}{ Cereals } & \multirow[t]{3}{*}{ Boiling } & Wheat & Increases starch & Edwards et al (2015) ${ }^{31}$ \\
\hline & & Barley & Increases starch & Xue et al $(1996)^{59}$ \\
\hline & & Oat & Increases starch & Ovando-Martinez et al (2013) ${ }^{60}$ \\
\hline & $\begin{array}{l}\text { Boiling + } \\
\text { dehydration } \\
\text { (instant rice) }\end{array}$ & Rice & Increases starch & Rewthong et al (2011) ${ }^{61}$ \\
\hline & Parboiling & Rice & Increases starch & Gunaratne et al (2013) $^{62}$ \\
\hline & Nixtamalization & Maize & $\begin{array}{l}\text { Decreases } \\
\text { starch }\end{array}$ & Sayago-Ayerdi et al (2014) ${ }^{63}$ \\
\hline & \multirow[t]{3}{*}{$\begin{array}{l}\text { Milling and } \\
\text { refining }\end{array}$} & Wheat & Increase starch & $\begin{array}{l}\text { Protonotarius et al (2015), } \\
\text { Edwards et al (2015) }^{65}\end{array}$ \\
\hline & & Barley & Increases starch & Livesey et al $(1995)^{32}$ \\
\hline & & Rice & Increases starch & $\begin{array}{l}\text { Muir \& Odea (1992), }{ }^{33} \text { Tamura } \\
\text { et al }(2016)^{66}\end{array}$ \\
\hline & $\begin{array}{l}\text { Baking (bread } \\
\text { making) }\end{array}$ & Wheat & $\begin{array}{l}\text { Reduces } \\
\text { proteins }\end{array}$ & Smith et al $(2015)^{67}$ \\
\hline & $\begin{array}{l}\text { Baking (bread } \\
\text { making) }\end{array}$ & Wheat & $\begin{array}{l}\text { Reduces } \\
\text { proteins (in the } \\
\text { crust) }\end{array}$ & Pasini et al (2001) ${ }^{68}$ \\
\hline & Extrusion & Maize & $\begin{array}{l}\text { Increases starch } \\
\text { and proteins }\end{array}$ & Robin et al (2016) ${ }^{69}$ \\
\hline & Fermentation & Sorghum & $\begin{array}{l}\text { Increases } \\
\text { proteins }\end{array}$ & Chavan et al (1988) ${ }^{70}$ \\
\hline \multirow[t]{8}{*}{ Legumes } & \multirow[t]{4}{*}{ Boiling } & Beans & \multirow[t]{2}{*}{ Increases starch } & \multirow[t]{2}{*}{ Eyaru et al (2009) ${ }^{71}$} \\
\hline & & Peas & & \\
\hline & & Soybeans & $\begin{array}{l}\text { Increases } \\
\text { proteins }\end{array}$ & Morinaga $(1997)^{72}$ \\
\hline & & Chickpeas & Increases starch & Hawkins \& Johnson (2005) $^{73}$ \\
\hline & $\begin{array}{l}\text { Boiling }+ \\
\text { dehydration }\end{array}$ & Lentils & Increases starch & Aguilera et al (2009) ${ }^{74}$ \\
\hline & Milling & Lentils & $\begin{array}{l}\text { Increases } \\
\text { proteins }\end{array}$ & Melito \& Tovar (1995) ${ }^{49}$ \\
\hline & Milling & Beans & $\begin{array}{l}\text { Decreases } \\
\text { starch }\end{array}$ & Berg et al $(2012)^{75}$ \\
\hline & Pureeing & Soybeans & Increases & Chacko \& Cummings (1988) ${ }^{76}$ \\
\hline
\end{tabular}




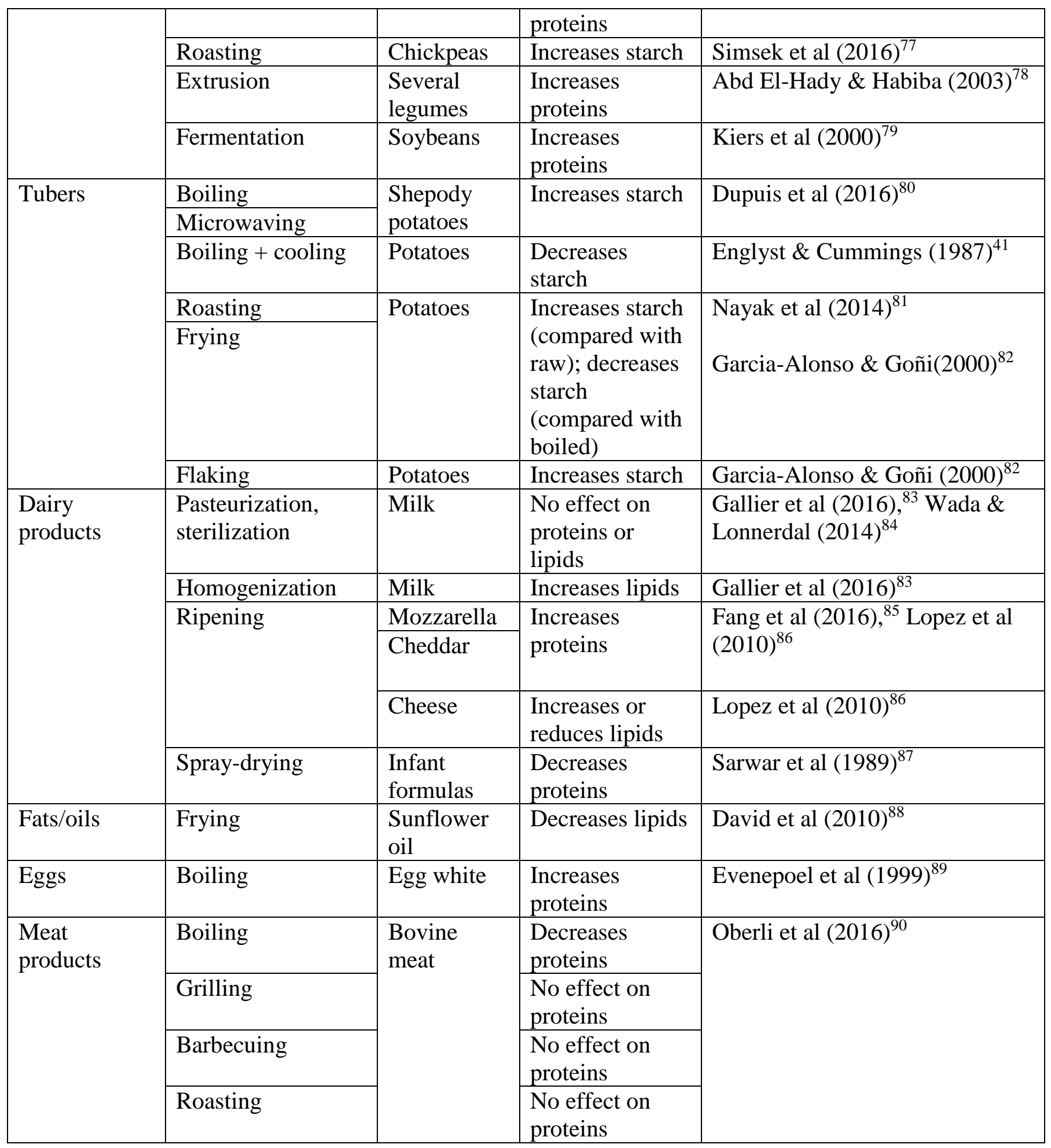




\section{Appendix S1. Calculation of the caloric content of diets.}

Compositional data for each food in the three diets were obtained from database of European Institute of Oncology, Food composition database for epidemiological studies in Italy (http://www.bda-ieo.it Published 2015. Accessed December 16, 2016). In the calculation scenario referred to as GENERAL, the energy content of the diets was calculated according to Regulation (EU) No 1169/2011, i.e. by using conversion factors of $4 \mathrm{kcal} / \mathrm{g}$ for proteins, $9 \mathrm{kcal} / \mathrm{g}$ for lipids, 4 $\mathrm{kcal} / \mathrm{g}$ for available carbohydrates (starch + sugars) and $2 \mathrm{kcal} / \mathrm{g}$ for dietary fibre. In the calculation scenario referred to as SPECIFIC, the energy content was calculated by using category-specific factors for total carbohydrates (starch + sugars + dietary fibre, calculated by difference from water, ash, lipids and proteins), lipids and proteins. Those factors were retrieved from, and are based on, the work of Merryll and Watt. ${ }^{\text {S1 }}$ In the calculation scenario referred to as CORRECTED, the energy content was calculated according to the following formula:

\section{Energy content}

$$
\begin{aligned}
& =[\text { starch }] \times \Delta H_{c, s} \times D G_{s}+[\text { monosaccharides }] \times \Delta H_{c, m} \times D G_{s m}+[\text { protein }] \\
& \times \Delta H_{c, p} \times D G_{p}+[\text { lipids }] \times \Delta H_{c, l} \times D G_{l}+[D F] \times \Delta H_{c, d f} \times D G_{d f}
\end{aligned}
$$

Where [starch], [monosaccharides], [proteins], [lipids], and [DF] are the amount of each nutrient, $\Delta H_{c}$ is the heat of combustion of each nutrient (for dietary fibre $\Delta H_{c, d f}$ is the heat of fermentation, whereas for proteins $\Delta H_{c, p}$ is corrected for the loss of urinary nitrogen, see Merrill and Watt, ${ }^{\mathrm{S} 1}$ Table 13) and $D G$ are digestibility values. Values for $\Delta H_{c}$ for each nutrient were retrieved from Table 13 in Merrill and Watt. ${ }^{\mathrm{S} 1} D G$ values were retrieved from in vivo intervention studies and whenever not available from studies on ileostomy patients. However, since small intestinal digestion of ileostomy patient may not fully reflect that of healthy subjects, caution must be use in the interpretation of these data from ileostomy patients. Wherever not available $D G$ values were retrieved from Merrill and Watt. ${ }^{\mathrm{S} 1}$ The literature sources used to retrieve $D G$ were as follows: protein digestibility in cooked eggs, ${ }^{\mathrm{S} 2}$ beans, ${ }^{\mathrm{S} 3}$ almonds, ${ }^{\mathrm{S} 4}$ walnuts, ${ }^{\mathrm{S} 5}$ “torrone” (assuming that all the proteins come from almonds) ${ }^{\mathrm{S} 4}$ and whole soybean. ${ }^{\mathrm{S} 6}$ For lipids: Emmenthal cheese (assuming an average digestibility 


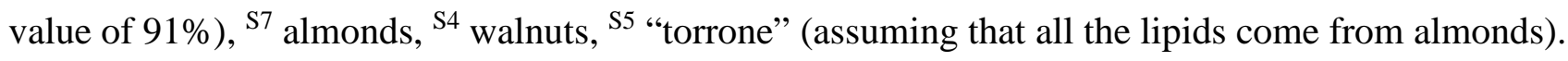
S4 The calculation of the energy coming from carbohydrates was more complicated. We recalculated the amount of additional starch entering the colon (true available starch) and thus the amount of additional dietary fibre (in the form of resistant starch) fermented in the gut (true dietary fibre) by using $D G$ factors for starch. $D G$ of monosaccharides was assumed equal to $100 \%$. Digestibility factors for starch were sourced as follows: beans ${ }^{\mathrm{s}}$, white bread and whole bread, ${ }^{\mathrm{S} 9}$ pizza, ${ }^{\mathrm{S} 10}$ pasta, ${ }^{\text {s9 }}$ rice. ${ }^{\text {s11 }}$ For whole bread, we assumed the same digestibility factor than white bread. For cooked and cooled potatoes, we used data from Englyst \& Cummings. ${ }^{\text {S12 }}$ For French fries, we used data of resistant starch from García-Alonso \& Goñi. ${ }^{\text {S13 }}$ However, to recognize the fact that the amount of available starch reported in the compositional table is already deprived of the resistant starch fraction measured in vitro, we have calculated the amount of true available starch by correcting for the difference between the resistant starch measured in vivo and that measured in vitro. The in vitro resistant starch was calculated from the \% of resistant starch making up the total amount of fibre. ${ }^{\text {S14 }}$ Simultaneously, the amount of dietary fibre was corrected by adding the same amount subtracted from the total starch.

An example of calculation for a typical food (i.e., dry beans) across the three different energy calculation systems is provided as Supporting Information on the publisher's website (Appendix S2).

\section{References}

S1. Merrill A, Watt B. Energy Value of Foods—Basis and Derivation. US Dept. of Agric, Agric Handb. No. 74, 105 pp. SI. Rev. 1973.

S2. Evenepoel P, Geypens B, Luypaerts A, Hiele M, Ghoos Y, Rutgeerts P. Digestibility of cooked and raw egg protein in humans as assessed by stable isotope techniques. J Nutr. 1998;128(10):1716-1722. 
S3. Friedman M. Nutritional value of proteins from different food sources. A review. J Agr Food Chem. 1996;44(1):6-29.

S4. Novotny JA, Gebauer SK, Baer DJ. Discrepancy between the Atwater factor predicted and empirically measured energy values of almonds in human diets. Am J Clin Nutr. 2012;96(2):296-301

S5. Baer D, Gebauer S, Novotny J. Atwater factors overestimate the calorie content of walnuts (371.1). FASEB J. 2014;28(1 Supplement).

S6. Chacko A, Cummings JH. Nitrogen losses from the human small bowel: obligatory losses and the effect of physical form of food. Gut. 1988;29(6):809-815.

S7. Renner E. Nutritional Aspects of Cheese. In: Fox PF, ed. Cheese: Chemistry, Physics and Microbiology: Volume 1 General Aspects. Boston, MA: Springer US; 1993:557-579.

S8. Noah L, Guillon F, Bouchet B, et al. Digestion of carbohydrate from white beans (Phaseolus vulgaris L.) in healthy humans. J Nutr. 1998;128(6):977-985.

S9. Jenkins DJA, Cuff D, Wolever TMS, et al. Digestibility of carbohydrate foods in an ileostomate - relationship to dietary fiber, invitro digestibility, and glycemic response. Am J Gastroenterol. 1987;82(8):709-717.

S10. Brighenti F, Casiraghi MC, Baggio C. Resistant starch in the Italian diet. Brit J Nutr. 1998;80(4):333-341.

S11. Muir JG, Odea K. Measurement of resistant starch - factors affecting the amount of starch escaping digestion in vitro. Am J Clin Nutr. 1992;56(1):123-127.

S12. Englyst HN, Cummings JH. Digestion of polysaccharides of potato in the small-intestine of man. Am J Clin Nutr. 1987;45(2):423-431.

S13. García-Alonso A, Goñi I. Effect of processing on potato starch: In vitro availability and glycaemic index. Nahrung. 2000;44(1):19-22.

S14. Gelroth JA, Ranhotra GS. Determination of resistant starch in selected grain-based foods. J Aoac Int. 2000;83(4):988-991. 
Appendix S2 Example: calories calculation for dry beans 
Table S1 Macronutrient composition of the three diets

\begin{tabular}{lccccc}
\hline & $\begin{array}{c}\text { Total } \\
\text { carbohydrate }^{1}\end{array}$ & $\begin{array}{c}\text { Sugars } \\
\mathrm{g}\end{array}$ & Proteins & Fat & Fibre \\
& $\mathrm{g}$ & $\mathrm{g}$ & $\mathrm{g}$ & $\mathrm{g}$ \\
\hline Western diet & 275.6 & 85.2 & 72.3 & 100.8 & 11.6 \\
Mediterranean diet & 302.6 & 99.0 & 79.1 & 86.8 & 44.0 \\
Vegan diet & 333.3 & 102.1 & 94.0 & 83.3 & 67.4 \\
\hline
\end{tabular}

${ }^{1}$ the sum of starch and sugar. 
Table S2 Food composition of the three diets

\begin{tabular}{|c|c|c|c|c|c|c|c|c|c|c|c|}
\hline \multicolumn{3}{|c|}{ Breakfast } & \multicolumn{3}{|c|}{ Snack } & \multicolumn{3}{|c|}{ Lunch } & \multicolumn{3}{|c|}{ Dinner } \\
\hline Food & $\begin{array}{c}\text { Food } \\
\text { composition }\end{array}$ & $\begin{array}{l}\text { Quantity } \\
\text { (g) }\end{array}$ & Food & $\begin{array}{c}\text { Food } \\
\text { composition }\end{array}$ & Quantity (g) & Food & $\begin{array}{c}\text { Food } \\
\text { composition }\end{array}$ & $\begin{array}{l}\text { Quantity } \\
\text { (g) }\end{array}$ & Food & $\begin{array}{c}\text { Food } \\
\text { composition }\end{array}$ & Quantity (g) \\
\hline \multicolumn{12}{|c|}{ Western diet } \\
\hline \multirow[t]{3}{*}{$\begin{array}{l}\text { Fried egg with } \\
\text { bacon }\end{array}$} & egg & 60 & Coffee & expresso coffee & 30 & $\begin{array}{l}\text { Cheesebu } \\
\text { rger with } \\
\text { French } \\
\text { fries }\end{array}$ & $\begin{array}{l}\text { Bread prepared } \\
\text { with oil }\end{array}$ & 100 & $\begin{array}{l}\text { Risotto } \\
\text { with } \\
\text { meat } \\
\text { sauce }\end{array}$ & white rice & 80 \\
\hline & bacon & 10 & & sugar & 5 & & $\begin{array}{l}\text { beef, fat and } \\
\text { lean meat }\end{array}$ & 100 & & beef, fat meat & 25 \\
\hline & butter & 10 & & & & & $\begin{array}{l}\text { Emmental } \\
\text { cheese }\end{array}$ & 20 & & pork, fat meat & 25 \\
\hline \multirow[t]{9}{*}{ Cappuccino } & moka coffee & 30 & & & & & mayonnaise & 20 & & $\begin{array}{l}\text { pancetta (pork } \\
\text { meat, salted, } \\
\text { raw) }\end{array}$ & 7 \\
\hline & whole milk & 100 & & & & & tomato & 10 & & $\begin{array}{l}\text { mortadella (pork } \\
\text { meat) }\end{array}$ & 5 \\
\hline & sugar & 5 & & & & & cucumber & 10 & & celery & 1 \\
\hline & & & & & & & salad & 5 & & onion & 3 \\
\hline & & & & & & & potato & 150 & & carrots & 2 \\
\hline & & & & & & & peanut oil & 20 & & tomato sauce & 12 \\
\hline & & & & & & Cola & & 200 & & corn oil & 5 \\
\hline & & & & & & Coffee & Expresso coffee & 30 & $\begin{array}{l}\text { Pizza } \\
\text { with } \\
\text { tomato } \\
\text { and } \\
\text { mozzarel } \\
\text { la }\end{array}$ & & 100 \\
\hline & & & & & & & sugar & 5 & Cola & & 200 \\
\hline \multicolumn{12}{|c|}{ Mediterranean Diet } \\
\hline $\begin{array}{l}\text { Yogurt with } \\
\text { almonds }\end{array}$ & $\begin{array}{l}\text { whole-milk } \\
\text { yogurt }\end{array}$ & 125 & $\begin{array}{l}\text { Apple } \\
\text { with the }\end{array}$ & apple & 150 & $\begin{array}{l}\text { Pasta } \\
\text { with } \\
\text { vegetable } \\
\text { sauce }\end{array}$ & wheat pasta & 80 & $\begin{array}{l}\text { White } \\
\text { beans } \\
\text { and tuna } \\
\text { salad }\end{array}$ & $\begin{array}{l}\text { Dried white } \\
\text { beans }\end{array}$ & 75 \\
\hline & almonds & 15 & & black the & 200 & & mushrooms & 80 & & canned tuna in & 50 \\
\hline
\end{tabular}




$\begin{array}{llc}\text { Cappuccino } & \text { moka coffee } & 30 \\ & \text { whole milk } & 100 \\ \text { Bread with } & \text { whole wheat } & 75 \\ \text { marmalade } & \text { bread } \\ & \begin{array}{l}\text { orange } \\ \text { marmalade }\end{array} & 20 \\ & \end{array}$

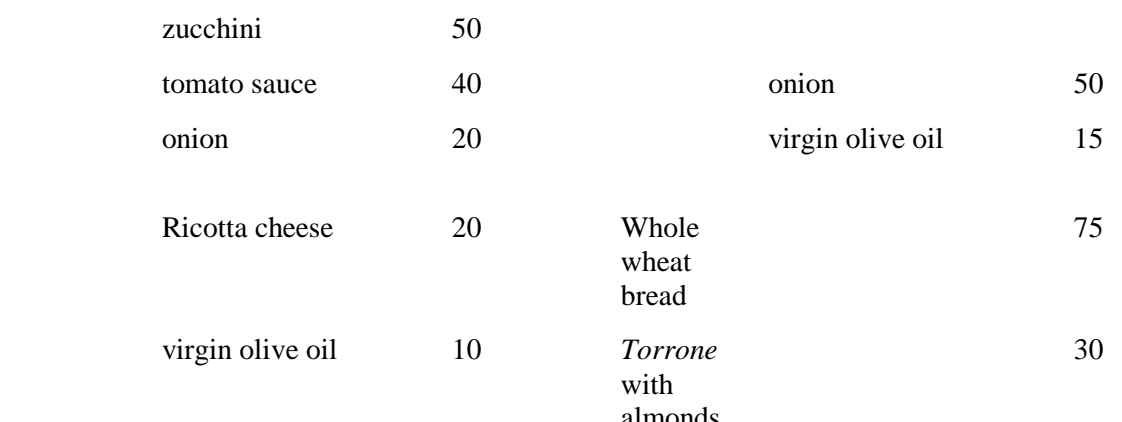

$\begin{array}{llc}\begin{array}{ll}\text { Mixed } \\ \text { salad } \\ \text { with } \\ \text { walnuts }\end{array} & \begin{array}{l}\text { parsley } \\ \text { chicory salad }\end{array} & 80 \\ & & \\ & \text { fennel } & 100 \\ & \text { apple } & 75 \\ & \text { celery } & 30 \\ & \text { walnuts } & 15 \\ & \text { virgin olive oil } & 15 \\ \begin{array}{l}\text { Whole } \\ \text { wheat } \\ \text { bread }\end{array} & & 50 \\ \text { Orange } & & \\ \end{array}$

\begin{tabular}{|c|c|c|c|c|c|c|c|c|c|c|}
\hline \multicolumn{11}{|c|}{ Vegan Diet } \\
\hline Orange juice & 200 & $\begin{array}{l}\text { Coffee } \\
\text { and kiwi }\end{array}$ & American coffee & 150 & $\begin{array}{l}\text { Pasta } \\
\text { with } \\
\text { creamy } \\
\text { chestnut } \\
\text { sauce }\end{array}$ & wheat pasta & 80 & $\begin{array}{l}\text { Beans } \\
\text { and } \\
\text { potato } \\
\text { salad }\end{array}$ & dried white beans & 75 \\
\hline Barley flakes & 30 & & kiwi fruit & 150 & & vegetable broth & 125 & & $\begin{array}{l}\text { cold boiled } \\
\text { potato }\end{array}$ & 200 \\
\hline almonds & 30 & & & & & chestnut flour & 25 & & pickled capers & 20 \\
\hline $\begin{array}{l}\text { whole wheat } \\
\text { bread }\end{array}$ & 75 & & & & & walnuts & 20 & & olives & 20 \\
\hline
\end{tabular}




\begin{tabular}{|c|c|c|c|c|c|c|c|}
\hline & 10 & & rosemary & 5 & & virgin olive oil & 10 \\
\hline \multirow[t]{8}{*}{$\begin{array}{l}\text { barley instant } \\
\text { coffee }\end{array}$} & 150 & $\begin{array}{l}\text { Soya } \\
\text { beans } \\
\text { salad }\end{array}$ & soya beans & 75 & & parsley & 10 \\
\hline & & & cucumber & 200 & & & \\
\hline & & & onion & 50 & & & \\
\hline & & & black olives & 10 & & & \\
\hline & & & basil & 10 & & & \\
\hline & & & lemon juice & 10 & & & \\
\hline & & & virgin olive oil & 10 & & & \\
\hline & & $\begin{array}{l}\text { Whole } \\
\text { wheat } \\
\text { bread }\end{array}$ & & 50 & & & \\
\hline
\end{tabular}


Example calories calculation for dry beans

composition of dry beans ( $75 \mathrm{~g}$ )

Content (g)

$\begin{array}{lr}\text { proteins } & 17.7 \\ \text { fat } & 1.88 \\ \text { starch } & 35.78 \\ \text { sugars } & 3 \\ \text { fiber } & 12.75\end{array}$

calories content GENERAL

Content (g)

$\begin{array}{ll}\text { proteins } & 17.7\end{array}$

fat $\quad 1.88$

$\begin{array}{lr}\text { starch } & 35.78\end{array}$

sugars 3

$\begin{array}{lr}\text { fiber } & 12.75\end{array}$

calories content SPECIFIC

Content (g)

$\begin{array}{ll}\text { proteins } & 17.7\end{array}$

fat $\quad 1.88$

$\begin{array}{lr}\text { starch } & 35.78\end{array}$

sugars 3

$\begin{array}{ll}\text { fiber } & 12.75\end{array}$

calories content CORRECTED

true starch=

digestible starch measured in vitro -

35.78

true fiber

total fiber measured in vitro +

Content (g)

proteins

17.7

fat

1.88

starch

31.3

sugars

fiber 
CONVERSION FACTOR $(\mathrm{kJ} / \mathrm{g})$

4

9

4

4

2

TOTAL CALORIES=

CONVERSION FACTOR (kJ/g)

3.47

8.37

4.07

4.07

4.07

TOTAL CALORIES=

\%total starch escaping digestion in ileostomy +

$-5.7248$

\%total starch escaping digestion in ileostomy -

5.7248

CONVERSION FACTOR $(\mathrm{kJ} / \mathrm{g})$

3.25

8.37

4.18

3.75 
CALORIES

70.8

16.92

143.12

12

25.5

268.34

\section{CALORIES}

61.419

15.7356

145.6246

12.21

51.8925

286.8817

\begin{tabular}{|c|c|c|}
\hline$\%$ of the in vitro DF represented by resistant starch & & e starch \\
\hline & 1.275 & 31.3302 \\
\hline$\%$ of the in vitro DF represented by resistant starch & & e fiber \\
\hline & -1.275 & 17.1998 \\
\hline CALORIES & & \\
\hline & 57.525 & \\
\hline & 15.7356 & \\
\hline & 130.834 & \\
\hline & 11.25 & \\
\hline & 34.4 & \\
\hline & 49.7446 & \\
\hline
\end{tabular}

